\title{
Lead Scrap Use and Trade Patterns in the United States, 1995-2012
}

U.S. lead waste and scrap exports
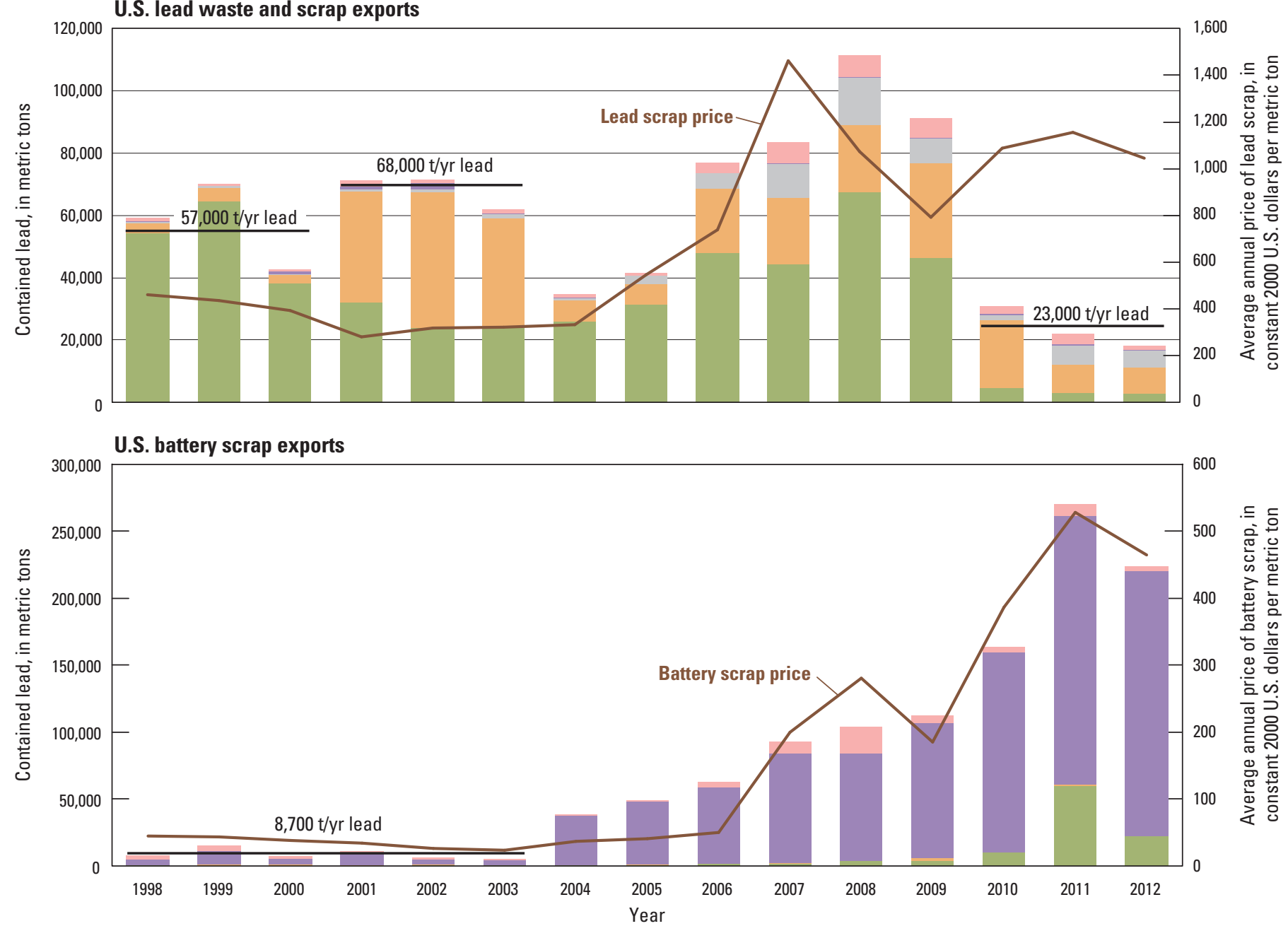

EXPLANATION

\begin{tabular}{|c|c|c|c|}
\hline Other countries & Asia (excluding & 8,700 t/yr lead & Average during \\
\hline Mexico & India) & & a 3- or 6-year \\
\hline India & Canada & & \\
\hline
\end{tabular}

Scientific Investigations Report 2015-5114 
Cover. Amount of lead contained in lead waste and scrap and scrap lead-acid batteries exported from the United States annually to principal destinations, 1998 through 2012. 


\section{Lead Scrap Use and Trade Patterns in the United States, 1995-2012}

By David R. Wilburn

Scientific Investigations Report 2015-5114 


\title{
U.S. Department of the Interior SALLY JEWELL, Secretary
}

\section{U.S. Geological Survey \\ Suzette M. Kimball, Acting Director}

\author{
U.S. Geological Survey, Reston, Virginia: 2015
}

For more information on the USGS - the Federal source for science about the Earth, its natural and living resources, natural hazards, and the environment—visit http://www.usgs.gov or call 1-888-ASK-USGS.

For an overview of USGS information products, including maps, imagery, and publications, visit http://www.usgs.gov/pubprod/.

Any use of trade, firm, or product names is for descriptive purposes only and does not imply endorsement by the U.S. Government.

Although this information product, for the most part, is in the public domain, it also may contain copyrighted materials as noted in the text. Permission to reproduce copyrighted items must be secured from the copyright owner.

Suggested citation:

Wilburn, D.R., 2015, Lead scrap use and trade patterns in the United States, 1995-2012: U.S. Geological Survey Scientific Investigations Report 2015-5114, 20 p., http://dx.doi.org/10.3133/sir20155114.

ISSN 2328-0328 (online) 


\section{Contents}

Abstract
Introduction
Sources of Domestic Lead
Regulations, International Agreements, and Emission Standards
Lead Scrap Trade
Conclusions
References Cited

\section{Figures}

1. Flow charts showing the generation and distribution of U.S. lead scrap in 1998 and 2011

2. Graph showing components of the U.S. lead supply reported annually from 1995 through 2012.

3. Graph showing annual world production of secondary refined lead for selected countries from 1995 through 2012 and cumulative world production

of primary plus secondary refined lead for the same period

4. Graph showing contribution of the scrap lead industries of China, Europe, India, and the United States to the global industry, expressed in terms of percentage of lead produced in-country compared to the total global lead production from secondary lead refineries for the years 1995 through 2012

5. Graph showing annual constant-dollar prices for selected scrap products containing lead, 2000 through 2012.

6. Graph showing percentage of total U.S. lead production attributed to recycled scrap batteries, 1995 through 2012

7. Graphs showing amount of lead contained in lead waste and scrap and scrap lead-acid batteries imported into the United States annually from principal points of origin, 1998 through 2012.

8. Graphs showing amount of lead contained in lead waste and scrap and scrap lead-acid batteries exported from the United States annually to principal destinations, 1998 through 2012.

9. Graph showing contribution of the amount of lead contained in imported lead scrap and scrap lead-acid batteries from Canada and Mexico as a percentage of the total amount of lead contained in lead scrap and scrap lead-acid batteries imported from all countries into the United States for the years 1998 through 2012.

10. Graph showing contribution of the amount of lead contained in lead scrap and scrap lead-acid batteries exported from the United States to Canada and Mexico as a percentage of the total amount of lead contained in lead scrap and scrap lead-acid battery exports to all countries for the years 1998 through 2012 


\section{Conversion Factors}

\begin{tabular}{lcl}
\hline \multicolumn{1}{c}{ Multiply } & \multicolumn{1}{c}{ By } & \multicolumn{1}{c}{ To obtain } \\
\hline cubic meter $\left(\mathrm{m}^{3}\right)$ & 35.3147 & cubic foot $\left(\mathrm{ft}^{3}\right)$ \\
metric ton $(\mathrm{t})$ & 1.102 & short ton $(2,000$ pounds $)$ \\
microgram $(\mu \mathrm{g})$ & $2.204 \times 10^{-9}$ & pound avoirdupois \\
milligram $(\mathrm{mg})$ & $2.204 \times 10^{-6}$ & pound avoirdupois \\
\hline
\end{tabular}

\section{Abbreviations}

$\begin{array}{ll}\text { BCI } & \text { Battery Council International } \\ \text { CEC } & \text { Commission for Environmental Cooperation } \\ \text { EPA } & \text { U.S. Environmental Protection Agency } \\ \text { HTS } & \text { Harmonized Tariff Schedule } \\ \text { mg/dscm } & \text { milligram per dry standard cubic meter } \\ \text { Mt } & \text { million metric tons } \\ \text { Mt/yr } & \text { million metric tons per year } \\ \text { NAAOS } & \text { National Ambient Air Quality Standard } \\ \text { NAFTA } & \text { North American Free Trade Agreement } \\ \text { OECD } & \text { Organization for Economic Cooperation and Development } \\ \text { SLAB } & \text { spent lead-acid battery } \\ \text { SLI } & \text { starting-lighting-ignition [type of battery] } \\ \text { t/yr } & \text { metric ton per year } \\ \text { USGS } & \text { U.S. Geological Survey } \\ \text { USITC } & \text { U.S. International Trade Commission }\end{array}$




\title{
Lead Scrap Use and Trade Patterns in the United States, 1995-2012
}

\author{
By David R. Wilburn
}

\section{Abstract}

Since 1995, domestic production of lead has increasingly shifted from primary mining and smelting to the recovery of lead-bearing scrap by the secondary lead industry, which accounted for 91 percent of U.S. lead production in 2012. Increasingly stringent environmental regulations for lead emissions in the United States have contributed to the closure of primary lead refineries and the consolidation of the secondary lead industry. Domestic production of lead from the primary and secondary sectors in 2012 is essentially unchanged from the amount produced in 1995. The U.S. secondary industry produced an estimated 145,000 metric tons more refined lead in 2012 than it did in 1995, primarily by recovering lead from battery scrap, allowing the U.S. to maintain production at a level sufficient to supply much of the domestic demand for lead.

Exports of lead contained in batteries, electronics, and scrap and waste increased more than 380 percent from 1998 through 2011. Trade patterns of lead scrap products among Canada, Mexico, and the United States have changed since initiation of the North American Free Trade Agreement in 1994, providing more flexibility of movement of materials such as lead scrap among these three trading partners. Canada was the source of an average of 98 percent of the lead contained in scrap batteries imported into the United States during the period 1998 through 2012. Canada received about 92 percent of the lead contained in scrap and waste exported from the United States in 1998; Mexico received about 89 percent of the lead contained in battery scrap exported from the United States in 2012. Domestic secondary lead facilities have been able to maintain production because of increasing domestic and foreign supply of spent lead-acid vehicle batteries, which accounted for about 95 percent of U.S. secondary lead consumption in 2012. Increased industrialization in China, India, and the Republic of Korea has led to increased demand for lead concentrates, lead scrap, and refined lead from imported sources to supplement growing domestic production. Consequently, about 94 percent of the lead in ores and concentrate produced in the United States was exported to Asia in 2012 compared to about 18 percent in 1995, and about 72 percent of lead-based scrap was exported from the United States to Asian countries in 2012 compared to about 7 percent in 1995.

\section{Introduction}

Since 1995, the structure of the domestic lead industry has changed, and trade patterns of the secondary (scrap) lead industry have shifted. An understanding of the current use and trade patterns of lead scrap and the changes in lead scrap supply and demand that have taken place in recent years increases understanding of factors influencing industry economics and future sources of national supply. A goal of the U.S. Geological Survey (USGS) is to provide decisionmakers with the information necessary to ensure that the Nation has an adequate and dependable supply of minerals and materials to meet its defense and economic requirements. The public and private sectors rely on information related to the domestic and international flow of minerals to develop plans and policies; to inform them of possible interruptions or shortages of mineral supply; and to develop strategies to maintain a competitive position in the global economy. This study is focused on the U.S. lead industry; data on international trade flows are provided in order to show how regulatory and structural changes in the U.S. industry and industrialization in other countries have affected global consumption, supply, and trade.

This analysis draws upon annual data on lead scrap production, consumption, and trade reported annually by the USGS for the period 1995 through 2012. Although the domestic demand for lead has remained relatively constant since 1995, domestic production of lead has increasingly shifted from primary lead produced from mines to the recovery of lead scrap by the secondary lead industry. Scrap lead, derived principally from obsolete lead-acid batteries, accounted for 73 percent of U.S. refined lead production in 1995 and 91 percent in 2012. With the closure of the Herculaneum, Mo., primary lead smelter in 2013, all primary lead concentrates now are exported, and lead scrap has become the sole domestic source of refined lead production in the United States. This analysis was undertaken to identify how the industry has changed over the study period, discuss the factors that brought about such changes, and evaluate the 2012 lead supply situation in light of these changes.

In this study, two sources of lead-containing scrap have been evaluated, spent lead-acid batteries (often referred to as SLABs or battery scrap) and lead recovered from battery and 
non-battery waste and scrap (excluding whole spent batteries). These two forms represent more than 99 percent of the total lead scrap processed or traded in the United States. Old scrap refers to scrap derived from obsolete lead-containing products; new scrap refers to lead-containing material generated during the manufacturing process; home scrap refers to scrap used internally during the production of refined lead.

The form of lead that is recovered from scrap depends on the source of scrap and the designated end-use market for that scrap. Soft lead contains few metal impurities and is most often derived from high-purity scrap metal that is suitable for refined lead and lead-alloy production. Antimonial (hard) lead can contain up to 10 percent antimony; the antimony content of this alloyed lead is about 5 percent. Antimonial lead is often used in batteries, lead sheet and pipe, pumps and valves, and radiation shielding. Lead-acid batteries contain both antimonial lead and soft lead; battery paste contains soft lead while battery grids and terminals typically contain antimonial lead. The amount of antimonial lead in automotive batteries has been reduced over the last 30 years to lessen the need for maintenance. Since 2001, a typical automotive lead-acid battery used in the United States has contained a maximum of 0.6 percent antimony (Carlin, 2014).

The structure and amount of lead-battery scrap recycling has changed as a result of changes in battery demand and type, consolidation of the secondary battery industry (battery recycling industry), improvements in spent-battery collection and distribution procedures, increased environmental regulation, upgrades in battery scrap processing and lead smelting technology, and variation in the composition of lead alloys. Since the mid-1980s, a significant shift in lead end-use patterns in the United States has taken place, primarily a result of U.S. lead consumers' compliance with environmental regulations that have significantly reduced or eliminated the use of lead in non-battery products such as gasoline, paint and glass pigments, potable water systems, and solders.

As demand for lead products has changed and leadrecycling-process technology has improved, the form of lead recovered from scrap has changed. In 1995, about 584,000 metric tons ( $\mathrm{t}$ ) (or 57 percent of secondary lead production) of soft lead and 400,000 $\mathrm{t}$ (39 percent of secondary lead production) of antimonial lead was recovered by the domestic secondary lead industry. By 2011, about $966,000 \mathrm{t}$ (or 85 percent of secondary lead production) of soft lead and $167,000 \mathrm{t}$ (15 percent of secondary lead production) of antimonial lead was recovered.

Although the use of lead in non-battery products has continued to decline, the demand for products that use lead-acid batteries, including starting-lighting-ignition (SLI) and industrial types, has continued to grow, so that by 2012, lead-acid batteries accounted for about 88 percent of U.S. reported lead consumption. The demand has continued to grow for SLI batteries used in automobiles; for non-SLI batteries used in motive sources of power for industrial forklifts, airport ground equipment, mining equipment, and a variety of off-road utility vehicles; and for non-SLI batteries used in stationary sources of power in uninterruptible electric power systems for hospitals, computer and telecommunications networks, and load-leveling equipment for electric utility companies. As the domestic battery industry has grown, so too has the amount of scrap batteries available for recovery.

From 1995 to 2012, global production of refined lead derived from scrap increased about 95 percent, primarily a result of growing demand for lead-based batteries used in automotive and industrial applications by the United States and countries with growing economies such as China and India. In 1995, the United States was the leading producer of refined lead derived from scrap and produced about 38 percent of the world's supply (Smith, 2001). By 2012, production of refined lead derived from scrap in China exceeded that of the United States, which now accounted for 21 percent of global production compared to 27 percent for China (Guberman, 2015). From 1995 through 2012, secondary lead metal production (including old and new scrap) in the United States increased from 1,020,000 $\mathrm{t}$ in 1995 to $1,110,000 \mathrm{t}$ in 2012, a 9 percent increase, primarily a result of increased recovery of spent lead-based batteries, at a time when the domestic secondary lead industry was consolidated from 25 companies processing lead scrap in 1995 to 11 companies in 2012. Industry consolidation took place primarily through mergers and acquisitions, as recyclers sought to adapt to more stringent environmental regulation and take advantage of economies of scale in this capital-intensive industry. Secondary lead is also produced from dross, dust, residue, and sludge generated by the smelting of metals; from lead pipe and sheet; from printing materials; from sheaths from power and telephone cables; and from vehicle wheel weights. Because of its corrosion resistance, lead-based scrap is available for recycling decades after it is produced, and lead contained in scrapped products can be recycled multiple times.

Data on consumption, production, and supply covering the years 1995 through 2012 are derived from USGS sources (Guberman, 2015; Papp, 2013; U.S. Geological Survey, 1996-2013). Data for 1998 were derived from USGS Circular 1196-F (Smith, 2004; U.S. Geological Survey, 2014). U.S. trade data are derived primarily from the U.S. International Trade Commission (USITC) for the years 1998 through 2012 (U.S. International Trade Commission, 2013), using a methodology developed for lead as reported in USGS Scientific Investigations Report 2006-5155 (Wilburn and Buckingham, 2006). USITC data were updated using revisions reported by the U.S. Census Bureau for selected countries for the years 2004-09 (U.S. Census Bureau, 2013). This analysis complements a 2014 USGS study on the U.S. lead recycling industry (Wilburn, 2014). Complete USITC trade data prior to 1998 are not available; as a result, graphics that include trade data are reporting the years 1998 through 2012. Unless otherwise noted, tonnages are expressed in terms of contained lead, rather than gross weight of scrapped batteries or other waste products. 


\section{Sources of Domestic Lead}

Over the study period, the supply of refined lead for the United States was made up of primary lead derived from domestic mines and secondary (recycled) refined lead produced at domestic refineries; net imports of refined lead, scrap lead, and lead contained in products that are scrapped; and sales of metal from industry stocks. The U.S. Government had liquidated the inventory of lead stored in its National Defense Stockpile by December 2006. With the closure of the last domestic primary lead smelter in 2013, lead from domestic mines was shipped overseas for processing and was no longer a direct source of domestic supply. It is likely, however, that lead originating from U.S. mines may be an indirect source of domestic lead scrap in that it is used in the manufacture of batteries overseas that subsequently are placed in vehicles and other products shipped to the United States.

Figures $1 A$ and $1 B$ show an overview of the generation and distribution of U.S. lead scrap for 1998 and 2011, respectively. Throughout the life cycle of lead production and use, scrap lead is generated. Some lead scrap is generated in manufacturing (new scrap). Lead-containing copper scrap is returned to the copper industry and lead scrap is returned to the secondary lead sector for reuse after some form of treatment. Other scrap is generated from end-of-life products (old scrap) and is collected by the secondary lead sector for recovery or export. A small amount of lead generated during processing is dissipated into the environment and is not recovered. The year 2011 reflects the year with the most complete data available at the time of report preparation.

Scrap production and trade data were available for the period 1998-2011 for all countries. However, U.S. trade data with Canada and Mexico were available for 1998-2012. For the study period, several observations can be made:

- Overall, domestic production of old plus new scrap from the primary and secondary lead industries was essentially unchanged.

- The United States generated about 60 percent less new scrap and 3 percent more old scrap in 2011 than it did in 1998.

- Exports of lead contained in exported scrap batteries, lead-containing electronic scrap, and reclaimed scrap lead from the United States increased over 380 percent from 1998 to 2011.

- Canada and Mexico together accounted for about 88 percent of the lead contained in U.S. lead scrap and battery scrap (SLABs) exported from the United States in 1998 and 92 percent in 2012; however, Canada was the principal export destination (accounting for about 92 percent of U.S. lead contained in scrap and waste exports) in 1998 and Mexico was the principal export destination (accounting for 89 percent of U.S. lead contained in scrap lead-acid battery exports) in 2012.
- The amount of material that is not accounted for has decreased 69 percent from 1998 to 2011. Such material includes material that is lost, stored, landfilled, or otherwise unaccounted for. The decrease may suggest that the U.S. industry has improved its material accounting, less material is lost to the environment, and (or) less lead-bearing material is being stored for future sale or use.

Figure 2 shows annual components of U.S. lead supply from 1995 through 2012. The makeup of domestic lead production shifted from primary plus secondary production in 1995 to mostly secondary production in 2012 . Domestic primary refined lead production decreased by 70 percent from about $374,000 \mathrm{t}$ (about 22 percent of total domestic lead supply) in 1995 to about 111,000 $\mathrm{t}$ (about 7 percent of total domestic lead supply) in 2012, and domestic scrap lead production increased about 9 percent from 1,020,000 $\mathrm{t}$ (about 61 percent of total domestic lead supply) in 1995 to 1,110,000 t (about 71 percent of total domestic lead supply) in 2012.

Imports and stock changes accounted for about 17 percent of total domestic supply in 1995 and about 22 percent in 2012. These figures do not reflect the high level of lead exports that took place from 2003 to 2009, which was primarily a result of increased demand by China for lead to support its growing industrial base. The increase in lead scrap exports from 2007 through 2009 was primarily the result of increased exports of lead scrap to Mexico as several domestic producers expanded their Mexican operations. A more detailed discussion of these trends is reported in the lead scrap trade section of this report.

In 1995, the U.S. primary lead industry was made up of 15 mines and 4 refineries. The Omaha, Nebr., refinery was closed in 1996 because the operator could not economically justify the investment required for environmental compliance (Smith, 1997). In 2001, ASARCO Incorporated suspended operations indefinitely at its East Helena, Mont., lead smelter, with an estimated refined lead capacity ranging from 60,000 to 75,000 metric tons per year (t/yr). In 2003, The Doe Run Company (Doe Run) suspended production at its Glover, Mo., facility, with an estimated capacity of 110,000 to $125,000 \mathrm{t} / \mathrm{yr}$ of refined lead, in response to declining domestic market and higher operating costs. In 2008, Doe Run closed one of its two furnaces at the Herculaneum, Mo., facility, reducing capacity from about 227,000 t/yr of refined lead to about 120,000 t/yr. By 2011, the primary lead industry had been consolidated to seven significant lead mines and the Herculaneum refinery (U.S. Geological Survey, 1996-2013). As domestic lead refinery capacity was reduced, a greater amount of lead concentrate produced domestically was exported. In 2012, nearly 62 percent of the lead in concentrate produced domestically was exported, and 88 percent of the lead in concentrate exports went to China (Guberman, 2015).

Doe Run closed its remaining furnace at Herculaneum on December 31, 2013, as part of a settlement agreement 


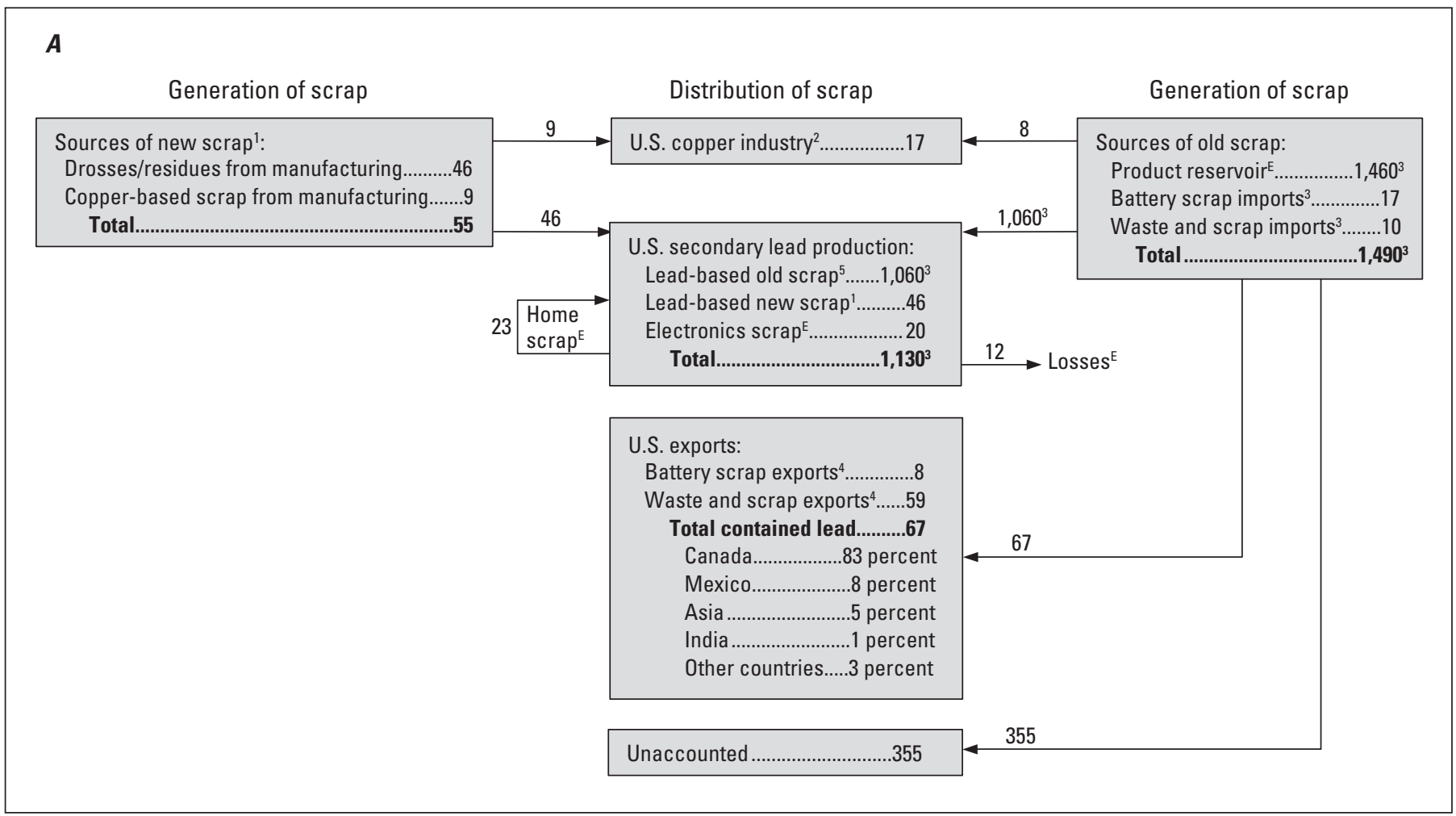

\section{B}

Generation of scrap

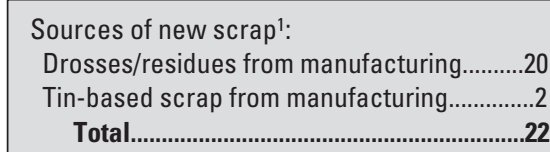

Distribution of scrap

Generation of scrap

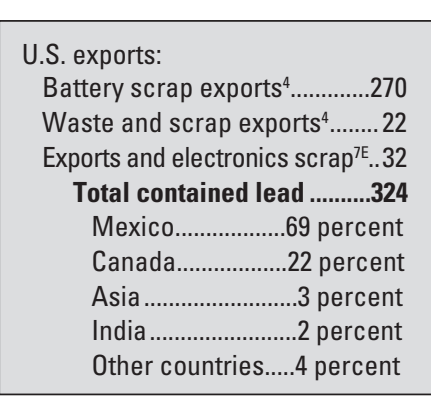

Unaccounted ...........................113

113

Figure 1. Flow charts showing the generation and distribution of U.S. lead scrap in $A, 1998$ and $B, 2011$. Values are expressed in thousands of metric tons of contained lead. Data may not total owing to rounding. Notes: E, estimate; 'U.S. Geological Survey (19962013); ${ }^{2}$ Edelstein (2001); ${ }^{3}$ rounded to three significant digits; ${ }^{4}$ U.S. International Trade Commission (2013); ${ }^{5}$ ead-based old scrap includes $1,010,000$ metric tons of lead contained in batteries and 47,000 metric tons of other lead-based scrap; ${ }^{6}$ Edelstein (2013); ${ }^{7}$ estimates are based on 2009 data and 2010 projections by U.S. Environmental Protection Agency (2012b). 


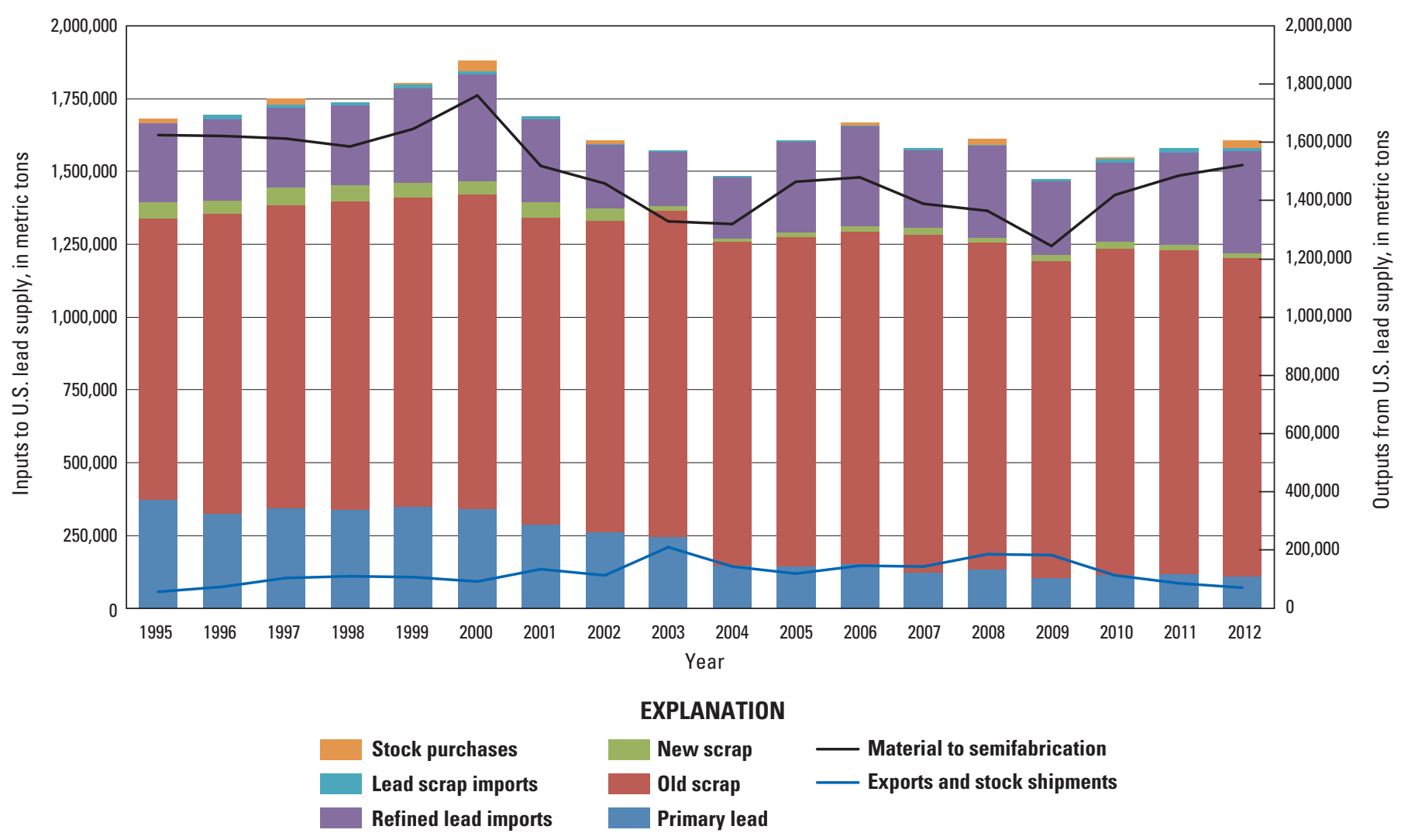

Figure 2. Components of the U.S. lead supply reported annually from 1995 through 2012. Inputs to domestic supply include primary lead production, lead recovered from old scrap and new scrap, refined lead and lead scrap imports, and lead stock purchases. Outputs to domestic supply include refined lead exports, lead scrap exports, and stock shipments; and material to semifabrication. Data are from Guberman (2015) and U.S. Geological Survey (1996-2013).

with the U.S. Environmental Protection Agency (EPA) and the State of Missouri. In 2012, the company dropped plans to build an electrowinning plant that would comply with current environmental regulations (The Doe Run Company, 2013). As a consequence, primary production of refined lead in the United States ended in 2013.

As the domestic primary lead industry was contracting in terms of the number of producing operations, the domestic secondary lead industry was restructuring, primarily in response to increasing costs associated with environmental regulation. Smaller operations found it difficult to justify the cost of adding environmental controls to meet increasingly stringent regulatory guidelines in times of low lead prices. In 1995, 23 companies produced secondary lead (Smith, 1996). By 2012, nearly all the secondary lead was produced by 7 companies operating 14 smelters (Guberman, 2015). Overall, domestic secondary lead production has increased in spite of the closure of some smaller recyclers and the consolidation of some smaller operations with larger operations, because capacities at some of the larger facilities have increased and a new plant in Florence, S.C., has begun production.

The U.S. secondary lead industry has been reduced in terms of the number of operating facilities since 1999 with the closure of the GNB Technologies, Inc., plant in Columbus, Ga., in response to low lead prices and high environmental compliance costs. The industry continued to restructure with the closure of Exide Technologies' 80,000-t/yr Baton Rouge, La., facility in 2009 and its 65,000-t/yr facility in Frisco, Tex., in 2012, and the idling of lead recycling operations at its 70,000-t/yr facility in Reading, Pa., in 2013; the 2010 expansion of the EnviroFocus Technologies facility in Tampa, Fla., to 100,000 t/yr; and the opening of the Johnson Controls, Inc., 120,000-t/yr secondary lead facility in Florence, S.C., in 2012. Exide Technologies suspended operations at its facility in Vernon, Calif., in April 2013 while investigating production options after the California Department of Toxic Substances Control reported the facility was not meeting State environmental standards (Recycling Today, 2013), but the facility was allowed to resume lead battery recycling operations in July 2013. The cumulative production capacity of the U.S. secondary lead industry by the end of 2013 was expected to be about 1.2 million metric tons (Mt) of lead per year, about 18 percent greater than its capacity in 1995 and slightly less than the combined production from the primary and secondary lead industry in the United States in 2011 of 1.25 Mt of lead per year (Guberman, 2013a). 
Lead Scrap Use and Trade Patterns in the United States, 1995-2012

Because of lower domestic demand for lead during the global economic downturn that took place from 2007 to 2009, environmental pressures on the domestic industry, and relatively high prices for refined lead and scrap over the period, the lead industry exported larger amounts of refined lead and lead scrap to Chinese and Indian markets, which were willing to pay a premium price for lead products for their growing industry. The amount of U.S. lead exports and stock shipments for the 2007-2009 period exceeded primary lead production for those years.

The secondary lead industry has been able to maintain its dominant supply position in the United States primarily owing to the continued use of SLI-type lead-acid batteries in the automotive sector, lead-based motive batteries of the type used in electric vehicles such as forklifts or golf carts, and stationary batteries used to provide standby power for large emergency lighting, security, telecommunications, and uninterruptible power systems. In 1995, battery scrap accounted for about 65 percent of U.S. lead production. About 95 percent of the lead recovered from old scrap processed in 1998 came from spent lead-acid batteries. The remainder came from other sources such as castings, sheet metal, solders, and miscellaneous fabricated parts (Smith, 2004). By 2012, battery scrap accounted for about 86 percent of U.S. lead production (or about 96 percent of the lead recovered from old scrap processed in 2012) (Guberman, 2013b). Approximately 79 percent of the lead generated from batteries recycled between 2007 and 2011 came from SLI batteries, 12 percent came from motive batteries, and 9 percent came from stationary batteries (Battery Council International, 2012).

Data compiled by the National Automobile Dealers Association show that the average age for passenger cars and light trucks still in use increased from about 9 years in 2001 to almost 11 years in 2011. This trend took place during a period when new car sales were generally decreasing (National Automobile Dealers Association, 2012). One might reasonably expect that as useable vehicle life is extended, more replacement batteries would be required over the life of the vehicle to maintain its operation. The total number of batteries in new and used vehicles has changed little since 2006. However, motor vehicle production data reported by the U.S. Bureau of Transportation Statistics and import data reported by the USITC show that the number of automotive batteries imported into the United States annually has increased from about 6,000,000 units in 1998 to about 18,000,000 units in 2012, while the number of new automobiles produced domestically and those that were imported decreased slightly from 12,750,000 units in 1998 to 12,260,000 units in 2012 (U.S. Department of Transportation, 2013; U.S. International Trade Commission, 2013). One could conclude from these data that the United States used an increasing number of batteries in used automobiles compared to new automobiles.

Recovery of lead scrap generated from electronic devices has increased as the combined weight of lead contained in collected scrapped devices has grown, increased production of batteries for new and used vehicles has generated more battery scrap over time, and regulations related to disposal of scrapped devices and replacement of obsolete devices have been implemented. On the basis of (1) electronic recycling data reported by the EPA for 2006 through 2009 and projections for 2010 and (2) estimates of lead content in selected electronic products reported by Occupational Knowledge International, approximately 53,000 $\mathrm{t}$ of lead was estimated to be contained in electronic products collected for recycling in 2011 and approximately $175,000 \mathrm{t}$ of lead contained in electronic scrap was estimated as potentially available for recovery in 2011 based on estimates of the number of units previously sold and on expected product life (Occupational Knowledge International, 2011; U.S. Environmental Protection Agency, 2011a). The USGS reported that about 40,000 t of lead was recovered from non-battery scrap in the United States in 2011, excluding electronics scrap (Guberman, 2013a). It is likely that much of the electronics scrap collected in the United States for recycling was shipped overseas for metal recovery.

Because the recycling process can be labor intensive and because lead contained in computer monitors and television screens having cathode ray tubes is considered hazardous waste, this material is costly to handle, separate, store, and transport; therefore these devices are often exported for recycling. In 2005, the Congressional Research Service reported that the EPA estimated 61 percent of discarded televisions having cathode ray tubes were sent overseas for recycling (Luther, 2010). Consequently, the historical domestic collection and subsequent recovery rate for lead from recycled electronics has been low, varying from about 40 percent of contained lead in computers to 11 percent of contained lead in mobile devices (U.S. Environmental Protection Agency, 2011a). This study assumes that all of the lead contained in electronic products collected for recycling is recoverable. USITC data suggest that about 4,900 t of lead was contained in electronic products exported from the United States in 2011, but this value is believed to include new and scrap products.

Lead recovered in the United States as old scrap from recycled batteries, electronics, or other reclaimed products accounted for about 59 percent of the available domestic lead supply in 1995 and about 72 percent of the available domestic lead supply in 2012. New scrap production derived from waste material collected from manufacturing and refining facilities in the United States accounted for 3.7 percent of domestic lead supply in 1995 and 1.3 percent of domestic lead supply in 2012. The contribution of this portion of lead supply has decreased over time with the closure of domestic primary lead refining capacity, as fewer domestic facilities produce new scrap.

The United States imported about 271,000 t of refined lead in 1995; no scrap lead imports were reported. In 2012, the United States imported 349,000 t of refined lead (Guberman, 2015), and an additional 13,000 t of lead was estimated to be contained in lead scrap imported for U.S. consumption. After 
accounting for lead, lead-scrap exports, and stock shipments, approximately 1,600,000 $\mathrm{t}$ of lead was supplied to domestic manufacturing facilities in 1995 and about 1,500,000 $t$ of lead was supplied to such facilities in 2012. U.S. lead production from primary and secondary sources was about 5 percent lower in 2012 than in 1995, and U.S. consumption of lead from primary and secondary sources was about 13 percent lower in 2012 than in 1995. An increase in imports of refined lead metal compensated for the lower primary lead production in the United States and provided the additional refined lead necessary to meet domestic demand.

Figure 3 shows annual world production of secondary refined lead for selected countries from 1995 through 2012 and cumulative world production of primary plus secondary refined lead for the same period. From 1995 through 2002, global primary lead production exceeded global secondary lead production. After 2002, however, global secondary lead production exceeded global primary lead production. The growth in both global sectors after 2003 was driven largely by the growth of industrialization in China, which led to the growth of the Chinese primary and secondary lead industries. Other factors influencing the growth of the secondary lead industry included increased consumption of lead, primarily in battery applications; increased regulation of the lead industry; increased incentives for recycling; and increased costs associated with the mining and processing of refined lead.

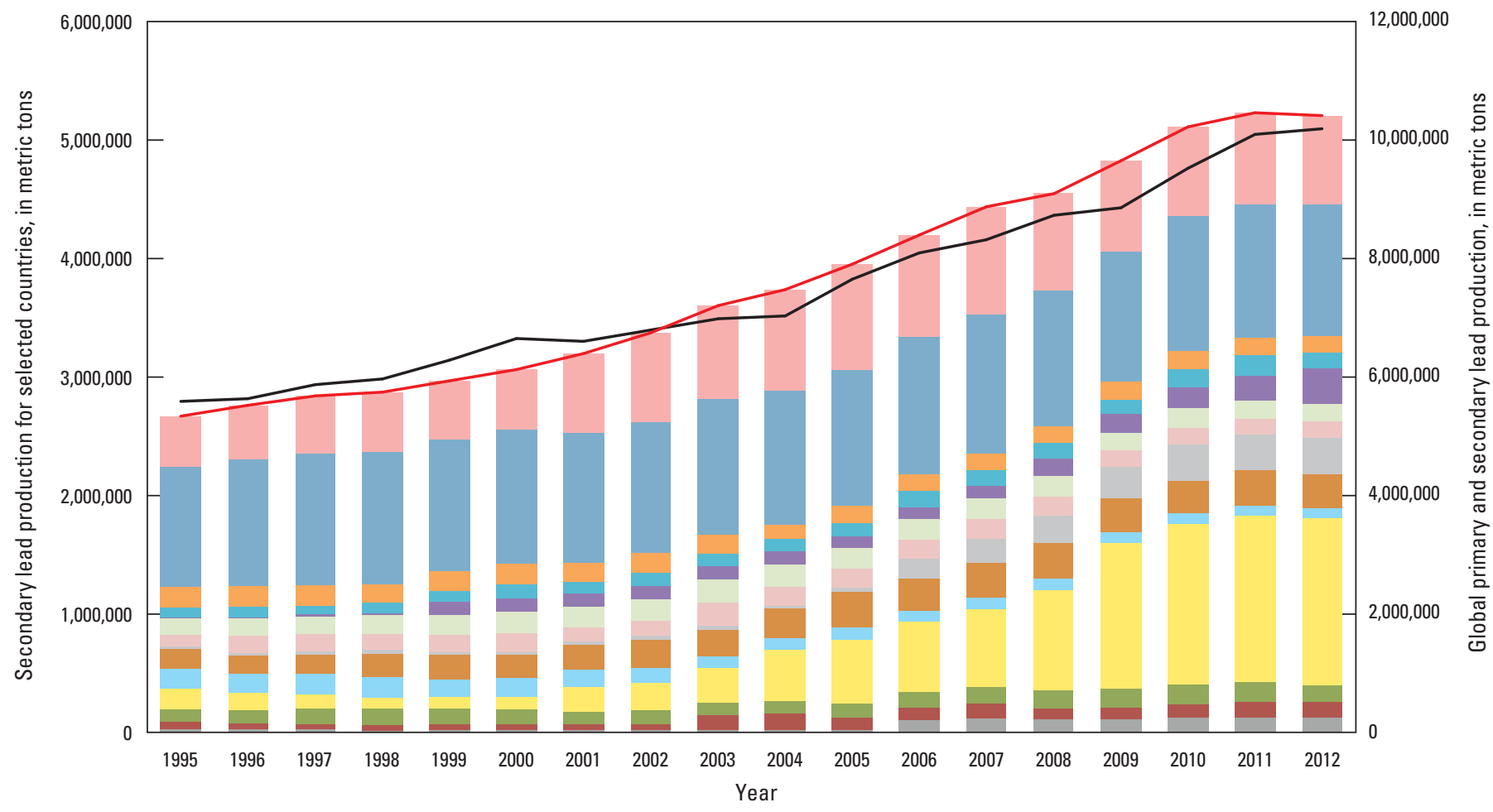

EXPLANATION
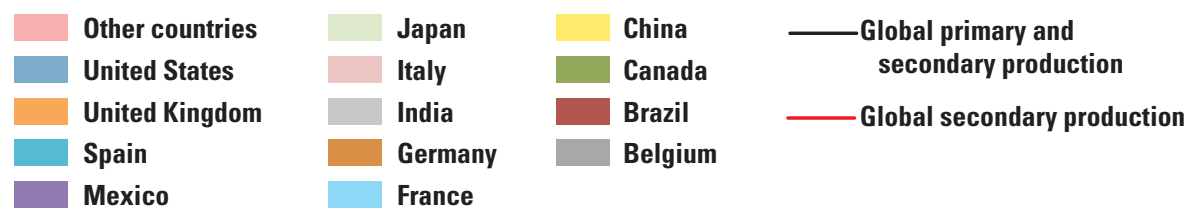

Figure 3. Annual world production of secondary refined lead for selected countries from 1995 through 2012 and cumulative world production of primary plus secondary refined lead for the same period. Global totals are reported for secondary lead on the left $y$-axis and for primary plus secondary lead on the right y-axis. Data are from Guberman (2015) and U.S. Geological Survey (1996-2013). 
The secondary lead industry in the United States accounted for about 38 percent of secondary refined lead production globally in 1995 and for about 21 percent of global secondary refined lead production in 2012 (fig. 3). U.S. production of lead contributed about 18 percent of global refined lead production in 1995 from both primary and secondary sources and about 11 percent of global refined lead production in 2012. Although the United States has increased secondary lead production since 1995, this increase was less than the corresponding increase in lead contained in scrap recovered in China, so the percent of global contribution from the U.S. secondary lead sector in 2012 was less than its contribution in 1995. China, Europe, India, and the United States together contributed up to about 80 percent of the global production of secondary lead during the study period. Figure 4 shows how secondary lead production from these areas has changed between 1995 and 2012. Increased industrialization in China has led to increased consumption of refined lead in China from domestic and imported sources. Primary lead production in China increased about 660 percent from 1995 through 2012 and secondary lead production increased about 700 percent. Figure 4 shows that China contributed about 7 percent of the global secondary lead in 1995 and about 27 percent of the global secondary lead in 2012. Much of this increase took place after 2000. India produced about 1 percent $(28,000 \mathrm{t})$ of the global secondary lead from scrap in 1995 and about 6 percent $(310,000 \mathrm{t})$ in 2012, a 1,000 percent increase. Much of this increase took place after 2005. Europe contributed about 33 percent $(890,000 \mathrm{t})$ of the global production of lead in scrap in 1995, and even though it increased its production to $1,140,000 \mathrm{t}$ in 2012, its percentage contribution of global production decreased to 22 percent (Guberman, 2013b).

Strong demand for lead in China and other emerging economies has influenced the price of lead and scrap lead, particularly since 2001 . The U.S. secondary lead supply has become an increasingly important component affecting the domestic lead price, and possibly global lead prices, as the United States is the second largest source of global lead supply. Domestic secondary refineries are increasingly competing with foreign producers for scrap as globalization takes place within the sector and lead prices increase. The reported average North American Producer price of refined lead was $\$ 0.453$ per pound in 1998 while the average price of refined lead was $\$ 1.22$ in 2012, an increase of 169 percent. The constant-dollar price of lead increased 79 percent from 1998 to 2012, when expressed in terms of the Consumer Price Index with a base year of 2000 (Guberman, 2015; U.S. Geological Survey, 2013, p. 82).

Figure 5 shows annual constant-dollar price estimates (base year 2000) for refined lead, lead scrap, battery scrap, and mixed brass scrap containing lead from 2000 through 2012. Scrap prices vary based on cost, demand, and quality factors. Lead prices were relatively low for the period 2000-2003 owing to high global inventories and lower demand from the automotive industry. Subsequent growing industrialization in

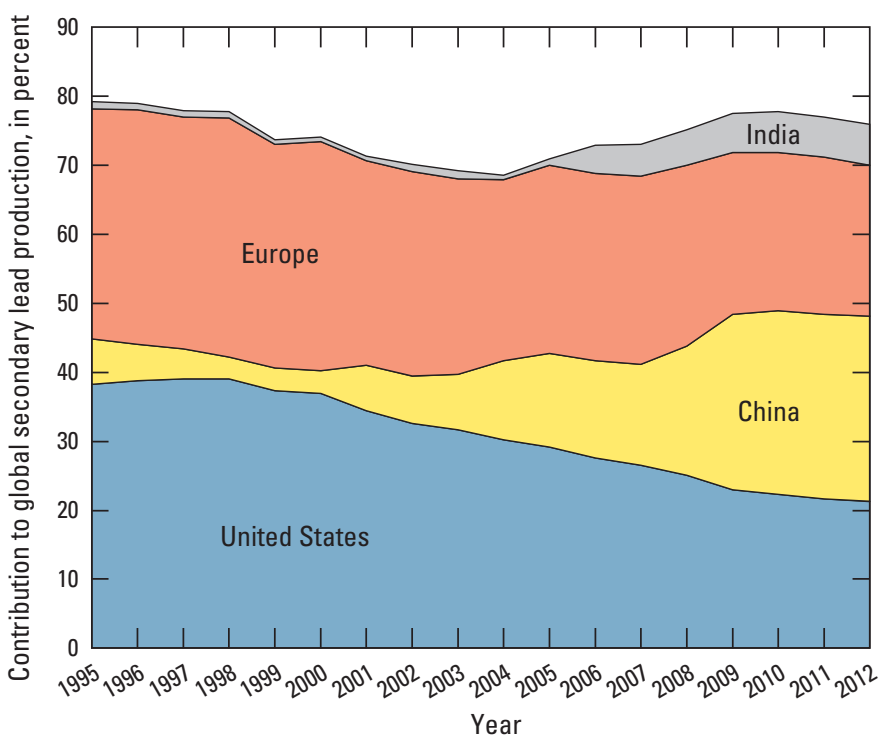

Figure 4. Contribution of the scrap (secondary) lead industries of China, Europe, India, and the United States to the global industry, expressed in terms of percentage of lead produced in-country compared to the total global lead production from secondary lead refineries for the years 1995 through 2012. The lead content of antimonial lead in batteries is included. Data are from Guberman (2015) and U.S. Geological Survey (1996-2013).

countries such as China and a strengthening global economy increased demand for lead products from 2004 to 2007, leading to higher prices for refined lead and lead scrap. China increased its production of lead-based products such as batteries, both for internal consumption and global export. According to the International Lead and Zinc Study Group, refined lead consumption in China increased 734 percent from 1998 to 2010 (U.S. Geological Survey, 2013, p. 82). High demand for metals in industrializing countries such as China required such countries to import metals necessary to supply their growing manufacturing industry. Products such as batteries were often produced then exported to global markets. Increasing global demand for such products stimulated the increase in metal and metal scrap prices that took place from 2002 to 2007.

Unsettled global economic conditions for the 2007-2009 period resulted in reduced demand for lead products, which resulted in a lead supply surplus and a decrease in lead prices during this period. Demand for lead battery scrap was not significantly affected, and the dip in battery scrap price was less than the decline in other lead prices, largely owing to sustained demand for lead batteries in China. Constant-dollar lead prices again increased after 2009 with renewed demand for lead in developing countries and for lead scrap in countries processing scrap.

Figure 6 shows the increasing contribution of recycled batteries on domestic lead production expressed in terms of the amount of lead recovered annually and as a percentage of total U.S. lead production. The percentage attributed to 


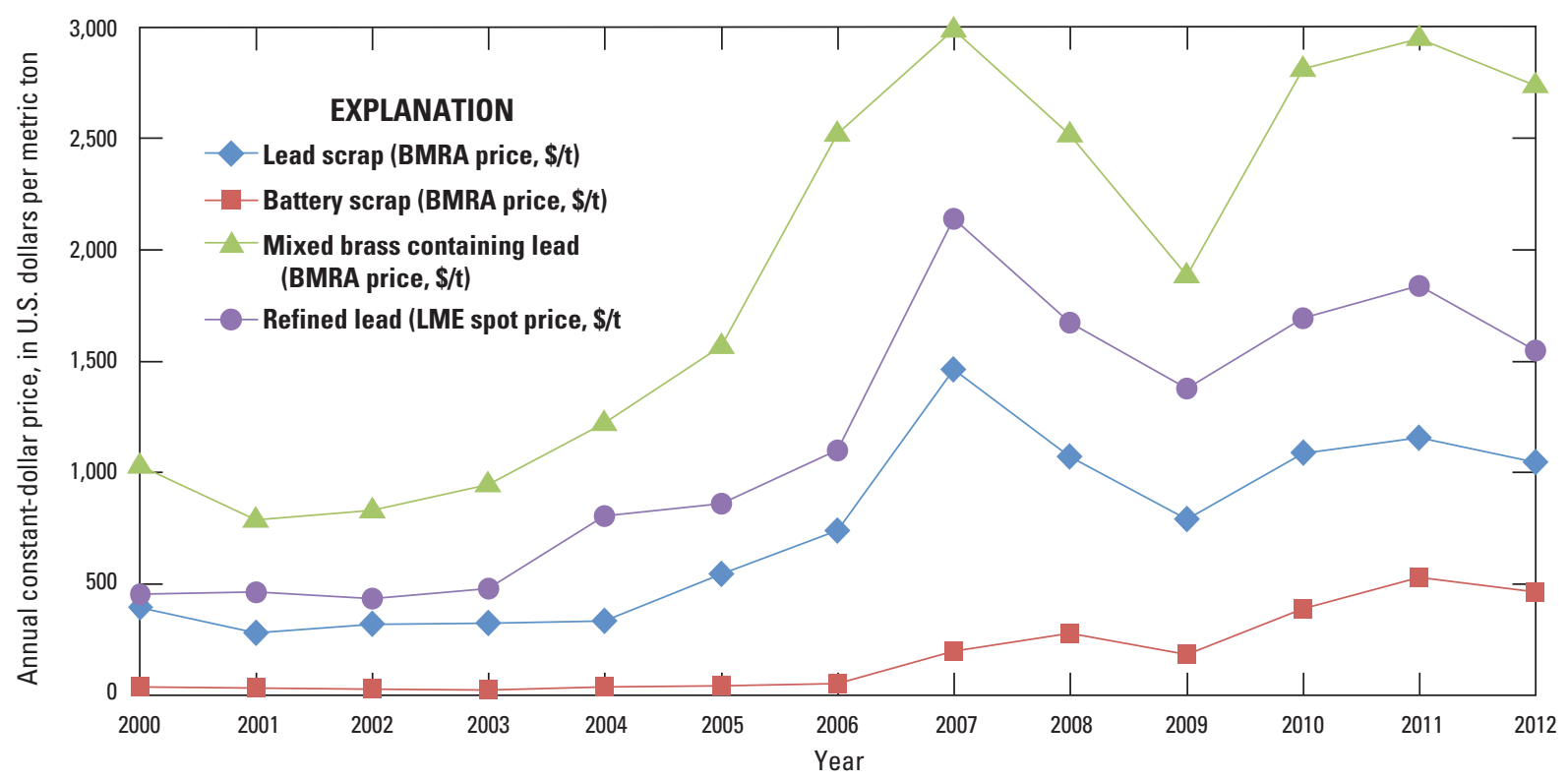

Figure 5. Annual constant-dollar prices for selected scrap products containing lead, 2000 through 2012. Prices are indexed using the Consumer Price Index, All Urban Consumers, with a base year of 2000 (U.S. Bureau of Labor Statistics, 2013). Refined lead prices reflect average annual London Metal Exchange (LME) spot price for 99.97 percent lead, including cost, insurance, and freight (CIF) for European ports, derived from IndexMundi.com (2013). Lead scrap, battery scrap, and mixed brass prices reflect data reported by Letsrecycle.com, as developed by the British Metals Recycling Association (BMRA) (Letsrecycle.com (2013). Abbreviation: \$/t, dollars per metric ton.

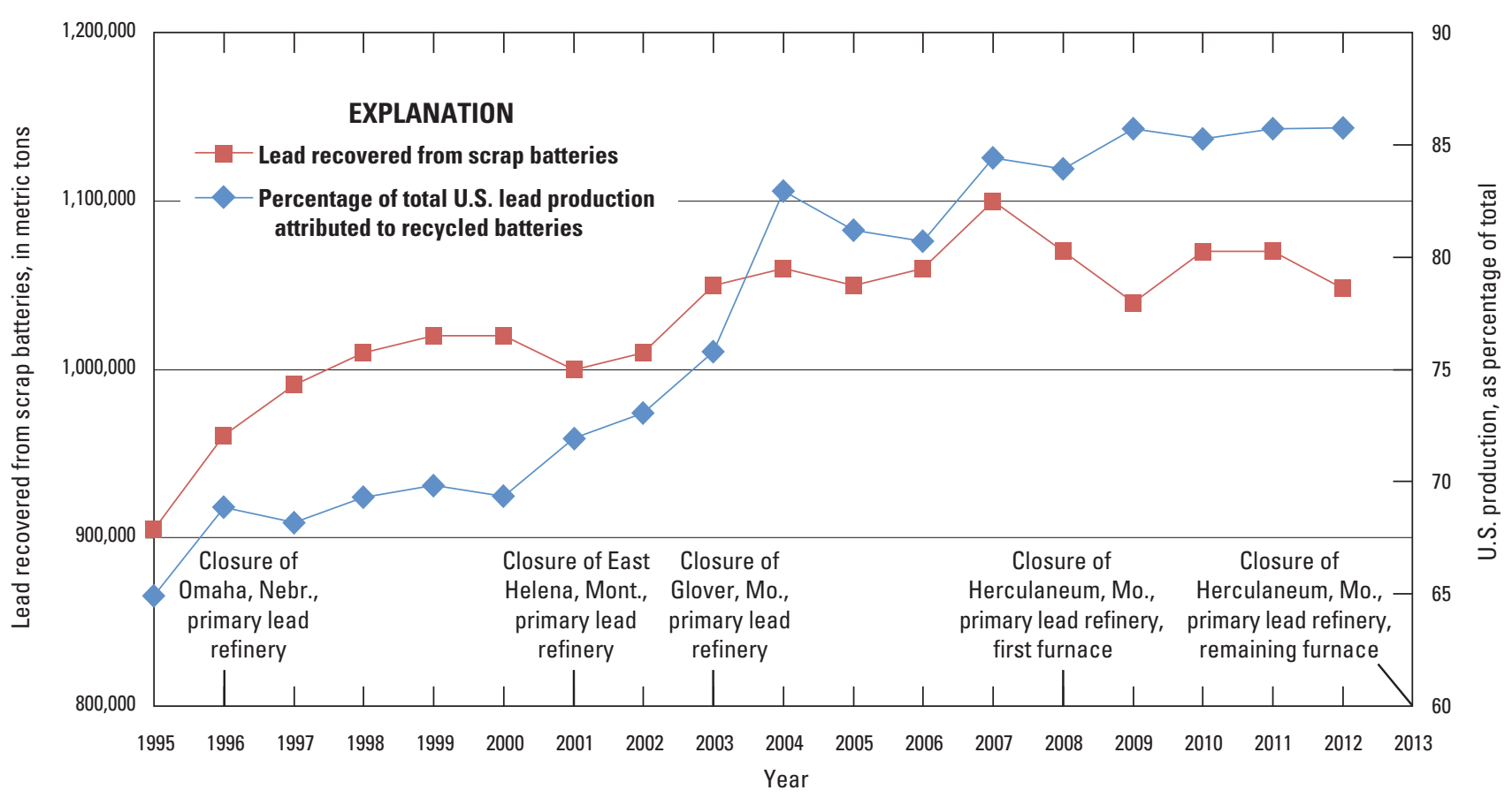

Figure 6. Percentage of total U.S. lead production attributed to recycled scrap batteries, 1995 through 2012. Data are from Guberman (2015) and U.S. Geological Survey (1996-2013). 
the recycling of lead-acid batteries has grown as domestic primary lead production has been curtailed and battery scrap production from new secondary production facilities has replaced older production facilities. Because lead batteries typically contain 5 percent antimony, they can also be a source for antimony. However, spent batteries are typically recycled to make new batteries, so the antimonial lead contained in these batteries is not further processed to recover separate lead and antimony.

Figure 6 also indicates the response of the secondary lead industry in the United States to reductions in primary lead supply. Reductions in primary lead production capacity took place in 1996, 2001, 2003, and 2008, when primary refining capacity was reduced either temporarily or indefinitely by facility closures. Secondary lead scrap production increased in the year following the closure of each primary lead refinery, as the domestic secondary lead industry increased production to support domestic and global market demand for refined lead. The U.S. secondary lead industry produced an estimated $145,000 \mathrm{t}$ more refined lead from recycled batteries in 2012 than it did in 1995.

Although refined lead produced by secondary refineries or recyclers may be substituted for refined lead produced by primary refining in most end uses such as automotive batteries, it is not always substitutable for high-purity applications or where impurities make it inadequate as a substitute. Some of the secondary facilities are dedicated to producing batteries only. Nearly all lead derived from recycled batteries is used to make new batteries or other applications such as ammunition or lead weights where lead purity is not critical. Impurities such as bismuth or silver are costly to remove from secondary lead, so applications that require high-purity lead (greater than 99.99 percent) may not be able to justify the use of refined lead produced from recycled scrap without removing such impurities. Examples of end-use applications that generally require high-purity lead are lead-acid batteries used in defense, such as for aircraft or submarines; certain types of power cable sheathing; and radiation detection equipment (David Guberman, lead specialist, USGS, written commun., November 21, 2013). Antimony is not considered an impurity if the end-use application requires antimonial lead.

\section{Regulations, International Agreements, and Emission Standards}

In addition to having been affected by changing lead demand and lead prices, the secondary lead industry in the United States has been affected by foreign regulations and agreements governing the trade of lead products. One way governments have chosen to reduce real and perceived hazards associated with the production and disposal of potentially hazardous materials such as lead is by regulating the import of materials that may contain hazards. The Basel Convention on the Control of Transboundary Movements of Hazardous Wastes and their Disposal, an international agreement signed by 168 countries and ratified by 165 of them, governs the trade of hazardous waste between member countries and bans trade between member and nonmember countries. A 1995 amendment to the convention, the "Basel ban," would essentially ban the export of hazardous wastes from developed to developing countries (Barlas, 2006), but as of September 2013, the amendment still needed ratification by 15 countries (D'Ambrosio, 2013). The United States signed the Basel Convention in 1992, but the U.S. Congress has not yet ratified it, in part because of concerns about the 1995 "Basel ban" amendment. Thus, the United States is forbidden from exporting hazardous wastes to any Basel signatory country unless that country has a bilateral or multilateral agreement with the United States that does not exclude trade of hazardous materials. One agreement permits the United States to trade in hazardous waste with any of the countries in the Organization for Economic Cooperation and Development (OECD), subject to certain conditions and reporting requirements. Revisions to this agreement pertaining to scrap lead-acid batteries were implemented in 2010 (U.S. Environmental Protection Agency, 2010). OECD countries include Australia, Canada, Japan, Mexico, New Zealand, the Republic of South Korea, the United States, and much of Europe. A further complication is that each participating country is allowed to set its own definition of "hazardous," and Basel signatory countries can change their list of banned products at any time (Barlas, 2006).

The North American Free Trade Agreement (NAFTA) among Canada, Mexico, and the United States, enacted in 1994, permits trade of lead batteries and scrap, providing that all member nations meet compatible human health standards. In Canada and the United States, increasingly stringent environmental regulations as discussed below have led to improvements in technology leading to a reduction in lead emissions; however, the level of compliance is uneven in Mexico (Commission for Environmental Cooperation, 2012). Newer facilities in the United States and Mexico managed by U.S. companies such as Johnson Controls, Inc., use technology capable of meeting or exceeding the more stringent U.S. environmental control standards. However, secondary lead processing facilities in Mexico are often small, with an annual capacity less than $30,000 \mathrm{t}$; consequently, they often do not have the necessary capital to implement emission control technology that is needed for the facility to meet the more stringent U.S. air toxic emissions standards for U.S. secondary lead smelters that became effective January 5, 2012 (Commission for Environmental Cooperation, 2012; U.S. Environmental Protection Agency, 2012a). 
The domestic secondary lead industry has also been influenced by changing State and Federal regulations and emissions standards. Federal law requires, with certain exceptions, spent batteries containing lead to be treated as universal waste as defined by the U.S. Code of Federal Regulations 40 CFR Part 273. The Universal Waste Rule issued by the EPA in 1995 prohibits handlers from disposing of waste lead-containing batteries in landfills and requires that these batteries be sent for recycling (U.S. Environmental Protection Agency, 2014). The Universal Waste Rule exempts the wastes from the more onerous hazardous waste requirements, as long as they are managed to prevent environmental releases and are properly recycled or disposed. In addition, 44 States have enacted regulations governing lead-acid battery use and disposal. State laws incentivize the recycling of batteries by banning the disposal of lead-acid batteries in landfills; establishing a deposit system for new battery sales; requiring retailers, wholesalers, and manufacturers to take back batteries; and by making it a violation to send SLABs to unlicensed recycling facilities in the United States (Battery Council International, 2013). EPA data suggest that about 96 percent of all automotive SLABs are recycled in the United States (U.S. Environmental Protection Agency, 2013). Non-automotive batteries, commonly used to power industrial equipment, emergency lighting, and alarm systems, use the same collection process as automotive batteries. The Rechargeable Battery Recycling Corporation, a nonprofit public service organization established in 1996, collects and recycles small sealed lead batteries as part of its recycling stream.

The EPA issued environmental regulations for lead processing facilities in June 1997 to establish limits for hazardous air pollutants from agglomerating furnaces, dryers, fugitive dust sources, refining kettles, and smelting furnaces (U.S. Environmental Protection Agency, 1997). The agency reduced the National Ambient Air Quality Standard (NAAQS) for lead from 1.5 micrograms per cubic meter $\left(\mu / \mathrm{m}^{3}\right)$ to $0.15 \mu / \mathrm{m}^{3}$ in 2008 (Schmidt, 2010). On December 16, 2011, the EPA updated the air toxic standards for secondary lead smelters, lowering the stack lead emission limits from 2.0 milligrams per dry standard cubic meter ( $\mathrm{mg} / \mathrm{dscm}$ ) for any individual stack to a facility-wide, flowweighted average emission limit of $0.20 \mathrm{mg} / \mathrm{dscm}$ with a limit of $1.0 \mathrm{mg} / \mathrm{dscm}$ applicable to any individual stack (U.S. Environmental Protection Agency, 2012a). The EPA estimated that the 2011 lead emissions from 9 of the 15 evaluated U.S. facilities producing in 2011 would likely result in ambient lead concentrations above the current NAAQS for lead of $0.15 \mu / \mathrm{m}^{3}$, mainly owing to excessive fugitive dust emissions (U.S. Environmental Protection Agency, 2011b). Implementation of these standards took place in January 2014.

The domestic lead industry has significantly reduced the level of lead emissions since 1998. Total lead emissions attributed to the domestic primary lead industry was $570 \mathrm{t}$ in 1998 and $54 \mathrm{t}$ in 2005, the most recent figure reported from the National Emissions Inventory by the EPA. The tenfold reduction in lead emissions from 1998 to 2005 was likely the result of stricter regulatory controls, modernization of facilities using improved technology, and the closure of production facilities that were not able to comply with environmental standards. In 2010, the domestic secondary lead industry had reduced the level of lead emissions to $23 \mathrm{t}$, a 95 percent reduction from the $460 \mathrm{t}$ reported for 1998 and a 56 percent reduction from the $52 \mathrm{t}$ reported for 2007 (Commission for Environmental Cooperation, 2012). The reader is referred to USGS Scientific Investigations Report 2014-5086 (Wilburn, 2014) for further discussion of this topic.

The United States, unlike Canada and Mexico, does not require a hazardous waste manifest to accompany each shipment of spent lead-acid batteries or battery waste because the U.S. Government does not consider lead-acid batteries to be hazardous waste. As the U.S. Congress has not yet enacted the requisite implementing legislation bringing U.S. law into conformity with the terms of the Basel Convention, shipping manifests are not mandated for trade with countries accepting spent lead-acid batteries or battery scrap (Bradford, 2011). As more lead-bearing battery materials are exported to countries such as Mexico that have less stringent environmental standards than in the United States or that are not enforcing existing standards, greater pressure is placed on the United States to adopt manifesting requirements and for countries receiving battery waste from the United States to adopt similar environmental standards (Commission for Environmental Cooperation, 2012; Occupational Knowledge International, 2011).

\section{Lead Scrap Trade}

In addition to data reported by the USGS, lead scrap trade statistics reported by Commodities Research Unit (now known as CRU); the Institute of Scrap Recycling Industries, Inc.; the International Lead and Zinc Study Group; Natural Resources Canada; Procuraduría Federal de Protección al Ambiente (Mexico); and the U.S. Environmental Protection Agency were considered for this analysis. Statistics were evaluated based on their availability for the years 1998 through 2012, level of detail, source(s) of information, and type(s) of data available. Lead trade patterns were in general developed using trade data provided by the USITC (U.S. International Trade Commission, 2013). USITC data was not complete prior to 1998. Data were revised using the corrected data reported by the U.S. Census Bureau as of 2013 for the years 2004-2010 for selected countries (U.S. Census Bureau, 2013). 


\section{Lead Scrap Use and Trade Patterns in the United States, 1995-2012}

In this study, two types of lead-bearing material have been evaluated, spent lead-acid batteries (battery scrap) and lead recovered from battery and non-battery waste and scrap (excluding whole scrapped batteries). These two forms represent more than 99 percent of total lead scrap processed or traded in the United States. Battery scrap includes spent leadacid batteries (U.S. Census Bureau Harmonized Tariff Schedule [HTS] code 8548100540), spent lead-based electrical storage batteries (HTS code 8548100580), and waste from batteries used for the recovery of lead (HTS code 8548102500). Lead waste and scrap includes lead-acid battery scrap (HTS code 7802000030) and lead-based non-battery scrap (HTS code 7802000060). USITC lead scrap import data are available from 1996 through 2012; USITC lead scrap export data are available from 1998 through 2012. Trade data reported in this study reflect contained lead values, unless otherwise noted.

Estimates for the amount of lead contained in various types of lead scrap were derived from actual data as reported by the USITC, or were estimated based on using the USITC lead content data, where reported, as a proxy for the lead content for that year and HTS code category, where not reported. The lead content in spent batteries, where not reported, was estimated using data reported by Battery Council International (BCI) for drained and undrained batteries. A drained battery was estimated to contain 73.6 percent lead by weight and an undrained battery was estimated to contain 58.6 percent lead by weight (Battery Council International, 2009). Based on BCI estimates, it was assumed for the purpose of this study that spent batteries transported among Canada, Mexico, and the United States were not drained prior to shipment, while spent batteries transported to or from other countries were drained prior to shipment.

USITC data for lead waste and scrap show different trade patterns than data for used lead-based batteries; this study will therefore discuss both sets of data, distinguish the differences, and suggest possible reasons for such differences. Trade patterns of imported and exported lead-based scrap will be discussed separately. Differences between USITC trade data and data from other sources will be noted and discussed.

Figure 7 shows USITC annual estimates of the amount of lead contained in (a) lead waste and scrap and (b) battery scrap imported into the United States for recycling from 1998 through 2012. Trade data for lead scrap and battery scrap show major shifts in trade patterns for these products. Import data for lead scrap have been divided into four timeframes, 1998 through 2001, 2002 through 2005, 2006 through 2009, and 2010 through 2012. As shown in figure $7 A$, an average of 11,900 t of lead was contained in lead waste and scrap imported annually into the United States from 1998 through 2001; much of this material was imported from South America, Canada, and Mexico (reported in descending order based on the amount of lead contained in the scrap imported). An average of 4,300 t of lead was contained in the lead waste and scrap imported annually from 2002 through 2005, primarily from South America, Canada, and Mexico. Although the exporting countries remain the same, the average amount of lead contained in the scrap imported from Canada decreased 75 percent during the 2002-05 timeframe from that in the 1998-2001 timeframe, and the average amount of lead contained in the scrap imported from South American countries decreased 56 percent. High domestic lead inventories, lower domestic automobile production, and the willingness of Chinese producers to pay premium prices for lead scrap to supply China's manufacturing industry reduced domestic imports of lead scrap during the 2002-05 timeframe.

About 4,800 t of lead scrap was imported annually from 2006 through 2009, primarily from Central America (excluding Mexico) and Canada. For the 2010 through 2012 timeframe, however, lead scrap imports to the United States increased significantly to meet domestic demand and to counteract decreasing domestic production of refined lead from the primary sector. Lead waste and scrap imports contained an average of about 14,200 t of lead per year, primarily from Central America (excluding Mexico), South America, and Mexico. Lead scrap and battery scrap prices from 1998 to 2004 were lower than corresponding prices from 2005 through 2012. The higher scrap prices can be attributed to increased Chinese demand for lead-based scrap, and the U.S. demand for processed scrap from Canada, Central America, and South America that likely was re-exported to China. Since 2005, Central America has been the largest exporter of lead scrap to the United States. Annual average lead waste and scrap imports from Central America increased about 820 percent from the 2002-05 timeframe to the 2006-09 timeframe and a further 310 percent from the 2006-09 timeframe to the 2010-12 timeframe. Scrap suppliers with limited capacity to recycle lead scrap, incentivized by increasing lead scrap prices, have shipped greater amounts of lead scrap to the United States for recycling or sale to overseas markets.

As shown in figure $7 \mathrm{~B}$, Canada accounted for almost all of the lead contained in used lead-acid batteries imported into the United States for processing from 1998 through 2012. Available USGS production and consumption data suggest that Canadian scrap production is nearly at the level of its processing capacity (Guberman, 2015; U.S. Geological Survey, 1996-2013); therefore, excess scrap collected by nonvertically integrated sources was shipped to the United States for processing. Mexico accounted for about 3 percent of the lead contained in used lead-acid batteries imported from 2006 through 2011, and Central America (excluding Mexico) accounted for about 4 percent in 2012. Scrap battery imports from these countries likely came from the smaller, nonvertically integrated sources that received a better price in the United States than if they had been processed in-country (Commission for Environmental Cooperation, 2012).

About 9,900 t of lead was contained in used lead-acid batteries imported annually into the United States for the 1998-2001 timeframe. About 7,400 t of lead was contained in used lead-acid batteries imported annually into the United States for the 2002-05 timeframe, about 15,500 t of lead was contained in used lead-acid batteries imported annually into the United States for the 2006-09 timeframe, 

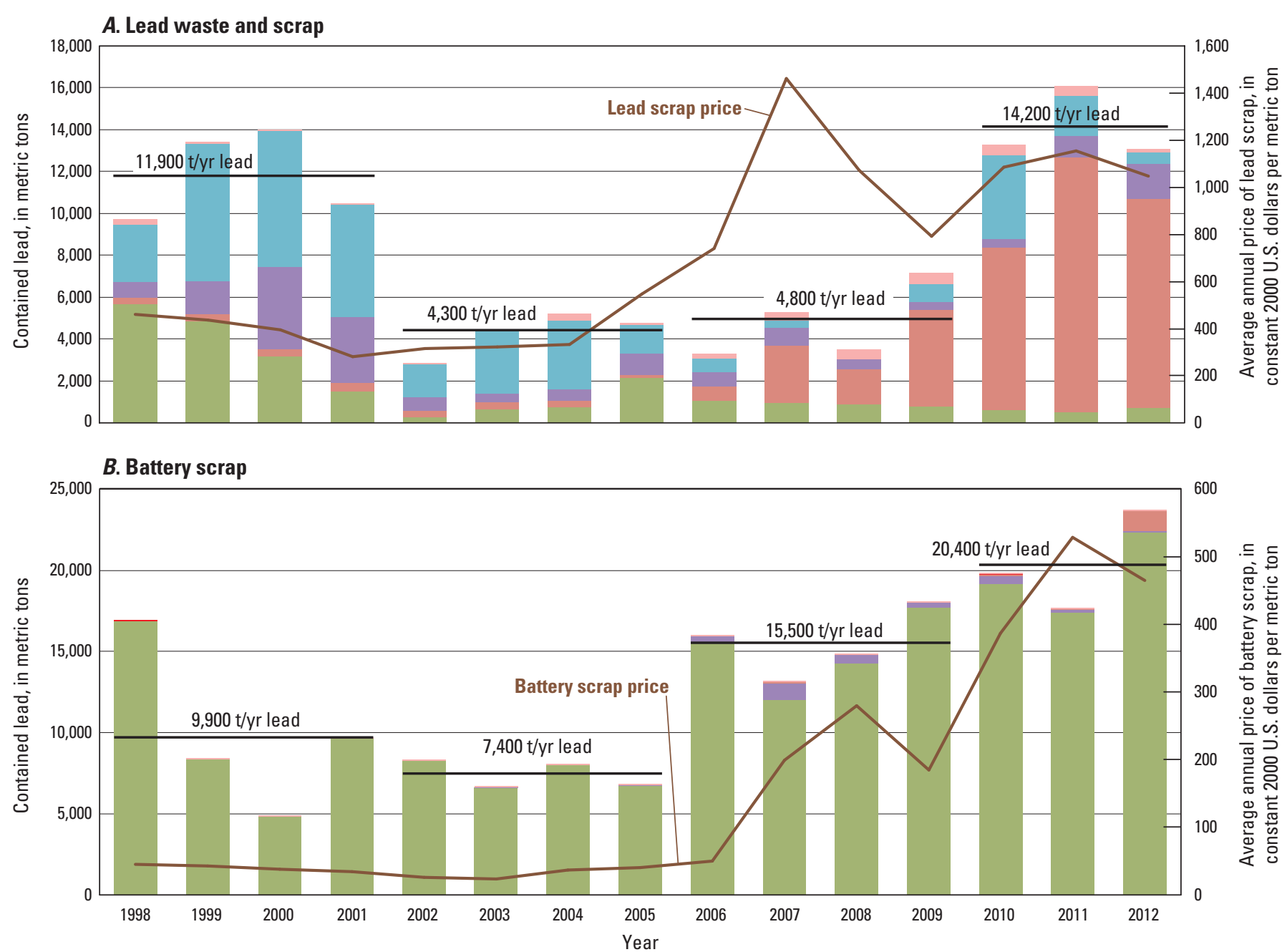

EXPLANATION

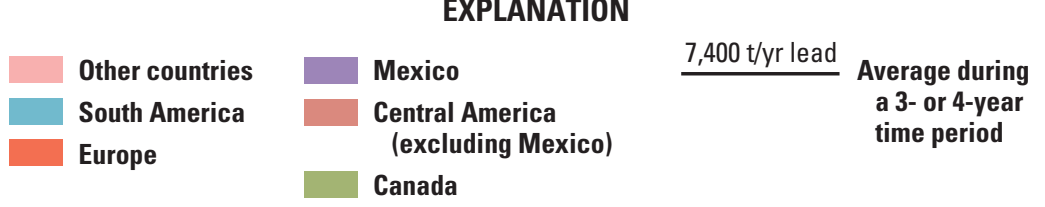

Figure 7. Amount of lead contained in $A$, lead waste and scrap and $B$, scrap lead-acid batteries imported into the United States annually from principal points of origin, 1998 through 2012. Constant-dollar lead scrap and battery scrap prices are also shown. Data are from U.S. International Trade Commission (2013) and U.S. Census Bureau (2013). Abbreviation: $t / y r$, metric tons per year.

and about 20,400 t of lead was contained in used lead-acid batteries imported annually into the United States for the 2010-2012 timeframe. The annual amount of lead contained in imported waste and scrap and battery scrap was lowest for the 2002-05 timeframe, again reflecting lower domestic demand, higher domestic inventories, and rising demand in China as it increased its domestic secondary lead processing industry. Both types of lead scrap were highest for the 2010-2012 timeframe because of higher scrap prices and continued demand from developing countries such as China.

For the 1998-2001 timeframe, the amount of lead contained in scrap lead-acid batteries imported annually into the United States was lower than the annual average of lead waste and scrap imported into the United States, accounting for about 45 percent of the lead contained in annual U.S. lead scrap imports. By 2002, however, the amount of lead contained in used lead-acid battery annual imports was consistently greater than lead waste and scrap imports, accounting for about 63 percent of the lead available from scrap products for the 2002-05 timeframe, 76 percent of the lead in lead scrap products for the 2006-09 timeframe, and 59 percent for the 2010-12 timeframe. U.S. lead scrap imports have more than doubled since 2005, in spite of the global recession that occurred from 2007 through 2009. In 2012, about 64 percent of this material was scrap derived from lead-acid batteries and about 36 percent was derived from non-battery scrap (USITC, 2013). 
More lead scrap from neighboring countries was processed in the United States as the domestic industry responded to more stringent regulations and international agreements affecting the processing and trade of lead scrap and spent batteries containing lead, as the industry improved its environmental and processing efficiency while maintaining capacity, and as higher lead scrap prices provided an incentive to recycle scrap.

Figure 8 shows annual estimates of the amount of lead contained in $(A)$ lead waste and scrap and $(B)$ battery scrap exported from the United States from 1998 through 2012. Export data for lead scrap and batteries can be broken out into four timeframes: 1998 through 2000, 2001 through 2003, 2004 through 2009, and 2010 through 2012. As shown in figure $8 A$, approximately $57,000 \mathrm{t}$ of lead contained in waste and scrap was exported annually from the United States from 1998 through 2000; about 92 percent of the lead in scrap was exported to Canada during this period.

About $68,000 \mathrm{t}$ of lead in scrap was exported annually from 2001 through 2003, primarily to eastern Asia (this report includes China, Hong Kong, Japan, the Republic of Korea, and Taiwan as the principal export destinations in Asia) (56 percent) and Canada (39 percent). During this timeframe, an average of about 4,300 t of battery scrap was exported to the Republic of Korea annually and an average of about $47,000 \mathrm{t}$ of non-battery scrap was exported to China annually. These countries were building their secondary lead processing capacity, but had not yet built up enough domestic scrap feed to supply their growing secondary lead demand. During the 2004-09 timeframe, lead scrap exports from the United States increased from about 35,000 t lead in scrap in 2004 to a peak of 111,000 $\mathrm{t}$ in 2008, decreasing to about 91,000 $\mathrm{t}$ in 2009. Principal export destinations during this timeframe were Canada (60 percent), eastern Asia countries (25 percent), and India (10 percent). The rise in lead scrap and battery scrap exports from the United States during this timeframe correlates well with the rise in lead scrap prices, driven by higher consumption of lead scrap in China, India, and the Republic of Korea. After 2009, however, exports of lead scrap declined to an annual average of about $23,000 \mathrm{t}$ of lead in scrap for the 2010-12 timeframe. Principal reasons for this apparent decline include a global surplus of refined lead; a clarification of lead scrap reporting procedures by the USITC, which resulted in a change in HTS coding by some countries for the 2004-09 timeframe; and increased enforcement of lead scrap import regulations by the Chinese Government, reducing the amount of certain types of lead scrap imported to China. The apparent increase in lead scrap exports to Canada shown in figure $8 \mathrm{~A}$ for the 2005-09 timeframe may partially reflect coding inconsistencies. The apparent decrease in lead scrap exports to Canada that took place during the 2010-12 timeframe is discussed further below. Available data suggest an overall decline in U.S. lead waste and scrap exports (excluding battery scrap) for the study period as more lead contained in scrap was exported annually from the United States from 1998 to 2004 than was exported annually for the 2010-12 timeframe (Commission for Environmental Cooperation, 2012).
Spent lead-acid battery (SLAB) exports increased from about 8,000 t of contained lead in 1998 to about $270,000 \mathrm{t}$ in 2011, as shown in figure $8 B$. Much of this increase can be attributed to an increase in SLAB exports to Mexico. Battery exports to Mexico averaged about 5,800 t per year of contained lead during the 1998-2003 timeframe, and then increased from about 37,000 $\mathrm{t}$ in 2004 to about 201,000 $\mathrm{t}$ in 2011. The United States exported about 198,000 t of lead in SLABs to Mexico in 2012, based on USITC trade data. U.S. SLAB exports to Mexico greatly exceed Mexican SLAB exports to the United States.

The data shown in figure $8 B$ suggest that spent-battery exports increased significantly after 2005. From 1998 to 2004, the annual growth rate of spent lead battery exports expressed in terms of lead content averaged 2 percent, while the annual growth rate for the years 2004 through 2012 was 13 percent. The growth rate would be even higher if Canadian data were shifted from figure $8 A$ to $8 B$. More stringent U.S. emission control standards may be one factor in the shift of lead-acid battery processing facilities to Mexico and corresponding increase in Mexican battery-processing capacity. Spent-battery exports to Canada after 2007 also increased, although to a lesser extent than to Mexico. As costs to comply with more stringent environmental controls increase, it becomes more difficult for smaller domestic secondary lead processors to compete with larger processors that have already spent capital to upgrade processing facilities to meet anticipated emissions standards. Some large secondary lead recyclers have shifted a portion of their North American operations to Mexico, where labor and processing costs are lower and environmental emissions standards are less stringent (Commission for Environmental Cooperation, 2012; Johnson, 2013). In 2004, Johnson Controls, Inc. (JCI) acquired the Ciénega secondary smelter in Mexico and began directing both U.S. and Mexicangenerated SLABs to that facility for recycling. In 2011, JCI opened the García secondary smelter in Mexico (Johnson Controls, Inc., 2013). As of 2011, JCI's operations in Mexico accounted for 74 percent of all SLAB exports from the United States to Mexico (Commission for Environmental Cooperation, 2012, p. 23). Since the opening of JCI's lead recycling plants in Mexico, a greater percentage of used leadacid batteries from the United States have been recycled in Mexico. Data are insufficient to estimate the quantity of lead that was recycled in Mexico and returned to the United States either as new batteries or as battery scrap intended for reuse by the U.S. battery industry.

Data compiled by the Commission for Environmental Cooperation (CEC) for SLAB exports to Mexico and Canada substantiate the significant growth trend in spent-battery exports from the United States since 1998, although trade data from various sources are inconsistent. SLAB data are included in the battery scrap data shown in figures 7-10. The CEC report pointed out some reporting errors within the USITC data, and differences in the reported values among the data reported by the USITC, EPA, and Environment Canada are attributed to reporting inconsistencies or different 

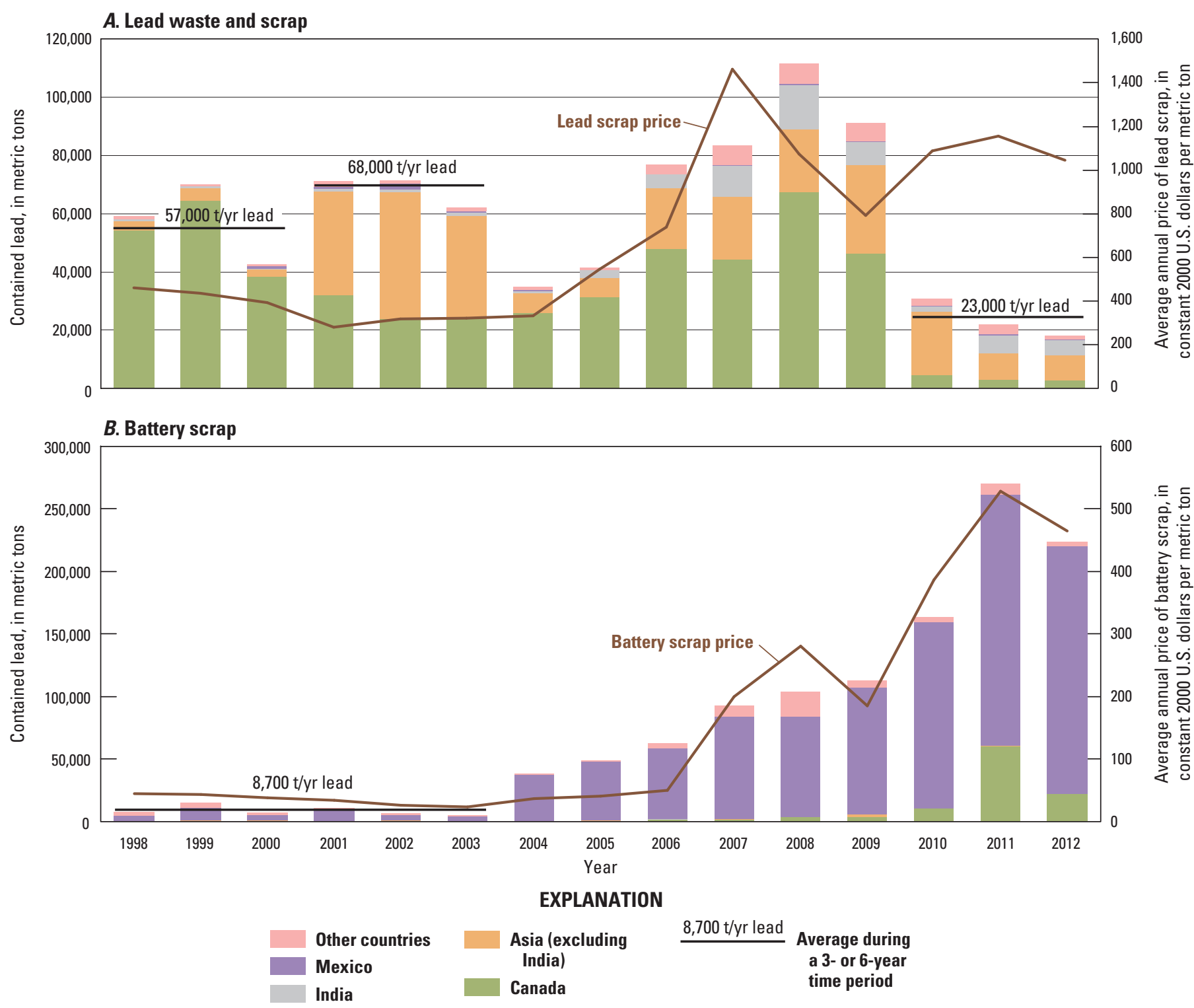

Figure 8. Amount of lead contained in $A$, lead waste and scrap and $B$, scrap lead-acid batteries exported from the United States annually to principal destinations, 1998 through 2012. Constant-dollar lead scrap and battery scrap prices are also shown. Asian countries include China, Hong Kong, Japan, the Republic of Korea, and Taiwan. Data are from U.S. International Trade Commission (2013) and U.S. Census Bureau (2013). Abbreviation: t/yr, metric tons per year.

systems of battery classification. The EPA and USITC use the U.S. Census Bureau HTS system while Environment Canada uses a system developed by the United Nations, which can include small sealed-cell batteries used by the electronics industry not included in the HTS classifications used in this study. The data for 2011 SLAB exports to Canada from the United States reflect a variation of 1.6 percent between the EPA and USITC data and 8.5 percent between the Environment Canada and USITC data (Commission for Environmental Cooperation, 2012, p. 28). The data for 2011 SLAB exports to Mexico from the United States reflect a variation of 13.8 percent between the EPA and unrevised USITC data and a 13.3 percent variation between data reported by
Mexico's Procuraduría Federal de Protección al Ambiente (Profepa) and the data reported by the USITC before it was revised (Commission for Environmental Cooperation, 2012, p. 24). The trade data used in this study were adjusted using revisions of selected country data released by the U.S. Census Bureau (U.S. Census Bureau, 2013). Although differences between USITC reported values and EPA estimates have not been reconciled, the general trends illustrated in this report should still be valid.

The USITC trade data shown in figure $8 A$ suggest that there was a general increase in lead waste and scrap exports to Canada from 2005 through 2008. Two secondary lead smelters, one in Ontario and one in Quebec, received about 
93 percent of the battery scrap from the United States in 2011 (Commission for Environmental Cooperation, 2012, p. 27). When USITC U.S.-Canada trade data are compared with data reported by Environment Canada, however, the data suggest that some U.S. exporters may have been improperly classifying lead scrap exports as HTS code 8548102500 rather than HTS code 7802000030 prior to 2010 (Commission for Environmental Cooperation, 2013, p. 25). If this is true, then a portion of the Canadian exports of lead waste and scrap shown on figure $8 A$ for the years 2005-09 should more correctly be included on figure $8 B$ for the same years. Thus, figure $8 A$ would show that the amount of lead waste and scrap exported to Canada for the 2005-12 timeframe would be decreasing, and the amount of lead contained in used lead-acid batteries exported to Canada would be increasing. This would be consistent with data reported by Environment Canada (Commission for Environmental Cooperation, 2013, p. 27).

Because complete trade data for lead scrap prior to 1998 are limited, assessing the effects of NAFTA on lead scrap trade among Canada, Mexico, and the United States since the agreement's enactment in 1994 is difficult. Trade data are reported by the USGS for battery and non-battery lead waste and scrap, but are not reported for spent lead-acid batteries.

Canada and Mexico have been the largest trading partners with the United States for lead waste and scrap, both before and after NAFTA. Canada processes the majority of lead waste and scrap exported from the United States, and the United States processes significant amounts of battery scrap exported from Canada. The average annual amount of lead waste and scrap exported to Canada (expressed in terms of gross weight) for 1990-93, prior to NAFTA, was about 49,000 t; the average annual amount of lead waste and scrap exported to Canada for 1995-2000 was 87,900 t. Imports of reclaimed lead waste and scrap from Canada decreased from an average annual amount of $171 \mathrm{t}$ (expressed in terms of lead content) for 1990-93, prior to NAFTA, to an average annual amount of $38 \mathrm{t}$ for 1995-2000. The amount of lead waste and scrap exported to Mexico decreased steadily from about 9,400 $\mathrm{t}$ (expressed in terms of gross weight) in 1990 to about $14 \mathrm{t}$ in 1997 . Since 1997, however, U.S. exports of lead waste and scrap have varied from a high of 3,040 $\mathrm{t}$ (gross weight) in 2002 to a low of $32 \mathrm{t}$ in 2005. After Johnson Controls, Inc., acquired the Mexican smelters, they may have considered any transfer of scrap between their U.S. and Mexican units as internal transfers rather than as international trade. Trade of lead waste and scrap among Canada, Mexico, and the United States after the turn of the century has varied widely; any trend that could be reported is likely not directly related to the existence of NAFTA.

Data for SLAB trade among Canada, Mexico, and the United States before and after NAFTA cannot be compared because no SLAB data are available prior to 1997. However, USITC data are shown in figures 7 and 8 for the period 1998 through 2012. The data show that Mexico recovered an increasing amount of battery scrap exported from the United States. The total amount of lead contained in imported scrap (batteries and non-batteries) from Canada and Mexico to the
United States increased about 6 percent from 1998 through 2012, and the total amount of lead contained in lead scrap exported from the United States to Canada and Mexico increased about 260 percent for this timeframe. The magnitude of lead contained in scrap exports from the United States is greater than 6 times that of lead contained in scrap imports, when averaged over the study period.

When trade statistics are viewed separately for Canada and Mexico, different patterns emerge. Figure 9 shows the total U.S. lead scrap imports (lead waste and scrap and SLABs) attributed to Canada and Mexico and reported as a percentage of the total global amount of lead contained in imported spent batteries and lead scrap from 1998 through 2012; figure 10 shows the same data for exports of scrap from the United States to these countries. These data are based on the revised trade data collected by the U.S. Census Bureau and reported by the USITC (U.S. Census Bureau, 2013; U.S. International Trade Commission, 2013), and exclude lead contained in new batteries. As shown in figure 9, the contribution of the total lead contained in spent batteries and lead scrap imported from Canada to the United States ranged from 43 to 86 percent of the total lead scrap imports from 1998 through 2012. One reason for this variation is related to Canadian supply of lead scrap versus its available processing capacity. In years where Canadian lead scrap supply exceeded its capacity to process this material, excess scrap was shipped to the United States for lead recovery. In years where supply was less than capacity, less scrap was shipped to the United States. The contribution of the total lead contained in spent batteries and lead scrap imported from Mexico to the United States ranged from 3 to 21 percent of the total lead scrap imports from 1998 through 2012, with an overall downward trend for the period. As Mexican capacity increased, less lead scrap was shipped to the United States for lead recovery. The enactment of NAFTA made it more cost effective for the industry to transport material such as lead scrap among these three countries in response to changing supply and demand conditions.

In terms of U.S. lead scrap exports, the trends are much more apparent. Figure 10 shows the total U.S. lead scrap exports attributed to Canada and Mexico for the period 1998 through 2012, reported as a percentage of the total amount of lead contained in all U.S. exports of lead scrap and scrap lead-acid batteries based on the revised data collected by the U.S. Census Bureau and reported by the USITC (U.S. Census Bureau, 2013; U.S. International Trade Commission, 2013). As shown in figure 10, the contribution of the total lead contained in lead scrap and scrap lead-acid batteries exported to Canada from the United States showed an overall decrease from about 81 percent in 1998 to about 10 percent in 2012. The contribution of the total lead contained in spent batteries and lead scrap exported to Mexico from the United States showed an overall increase from about 7 percent in 1998 to about 82 percent in 2012. As more lead contained in scrap and battery scrap was exported to Mexico, less was exported to Canada. 


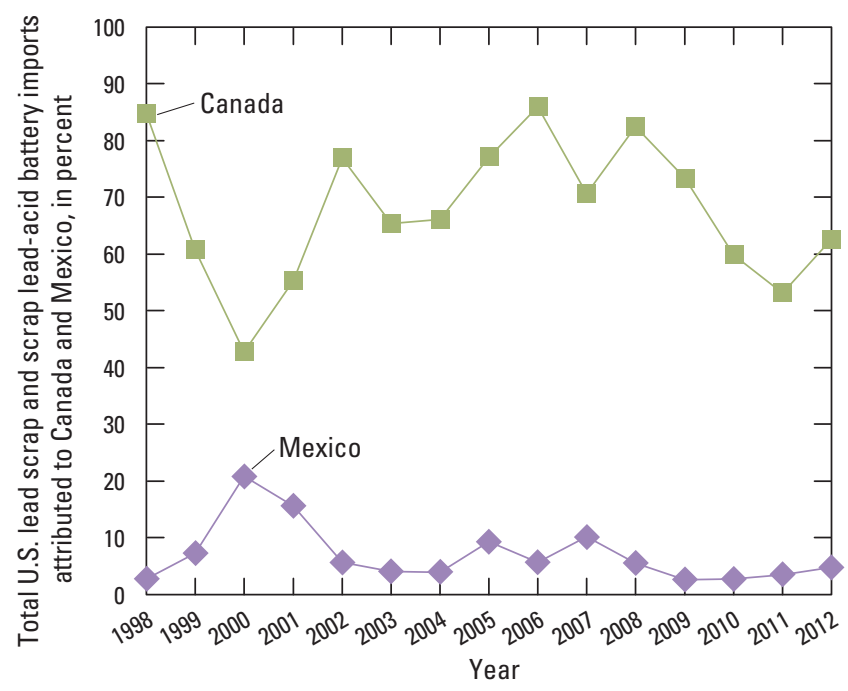

Figure 9. Contribution of the amount of lead contained in imported lead scrap and scrap lead-acid batteries from Canada and Mexico as a percentage of the total amount of lead contained in lead scrap and scrap lead-acid batteries imported from all countries into the United States for the years 1998 through 2012. Data do not include lead contained in new batteries imported into the United States. Data are from U.S. International Trade Commission (2013).

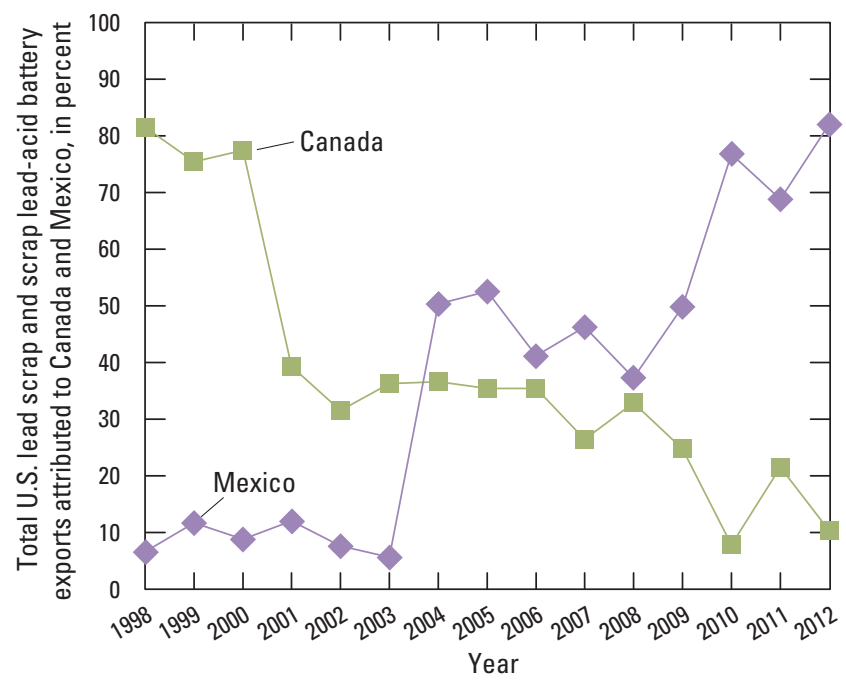

Figure 10. Contribution of the amount of lead contained in lead scrap and scrap lead-acid batteries exported from the United States to Canada and Mexico as a percentage of the total amount of lead contained in lead scrap and scrap lead-acid battery exports to all countries for the years 1998 through 2012. Data do not include lead contained in new battery exports. Data are from U.S. International Trade Commission (2013).

\section{Conclusions}

Although there have been changes in the domestic lead industry from 1995 through 2012, the U.S. supply/demand balance has been relatively stable. An overall decrease in primary lead production has been partially compensated for by increased secondary lead production at some facilities and increased imports of refined lead.

Since 1995, the U.S. lead industry has been able to meet domestic demand for refined lead by extracting lead from mineral resources, recovering lead derived from scrap products, drawing material from available stockpiles, and importing refined lead and lead scrap from other countries. The secondary lead industry in the United States has been able to maintain its production level primarily owing to the increased use of (1) SLI-type lead-acid batteries in the automotive sector, (2) lead-based motive batteries, (3) stationary batteries used in large emergency lighting, security, telecommunications, and uninterruptible power systems, and (4) other lead-containing products. With the closure of the last domestic primary lead smelter in 2013, the U.S. secondary lead industry became the sole domestic source of refined lead production, and lead concentrates from domestic mineral resources are now exported. Recovery of significant lead from scrapped batteries should continue in the short term, as lead-acid batteries continue to be the dominant battery used in most vehicles and as batteries from vehicles reaching the end of their life become available for recycling, unless substitution of lead-based batteries by lead-free batteries becomes widespread. Newer battery technologies in use and under development may eventually reduce or eliminate the use of lead in certain applications. These technologies are not likely to take place to any great degree as long as traditional leadbased batteries are being used in vehicles.

The amount of lead recovered from scrapped products has increased as more scrapped devices reach the end of their life, increased new car sales generate more battery scrap over time, and regulations related to disposal of scrapped devices and replacement of obsolete devices have been implemented. Although the total number of batteries used annually in the United States (in new and used vehicles) has changed little since 2006, the percentage of batteries in used vehicles has grown faster than the percentage of batteries attributed to new vehicles. The number of lead-acid batteries contained in scrapped vehicles should increase in the future when these vehicles are sold for scrap, dismantled, or exported.

Industrialization in China and India has led to increased consumption of lead products, particularly lead-acid batteries, and influenced the global price of lead and lead scrap, particularly since 2001. High demand for metals in China and India has required these countries to import needed metals to support their growing domestic primary and secondary lead industries, increased global demand for products manufactured in China, and stimulated the increase in metal and metal 
scrap prices. With the closure of primary lead refineries in the United States, lead ore and concentrates produced in the United States have increasingly been exported to China. At the same time, the U.S. secondary lead industry has become the sole domestic source of refined lead and lead scrap. The availability and supply of lead-containing scrap has become an increasingly important component affecting the domestic lead price, as domestic secondary refineries increasingly compete with foreign producers for scrap. The domestic secondary lead industry should benefit, however, from continued demand for original and replacement lead-acid batteries used in vehicles consumed in the United States and as it recycles lead from increasing numbers of scrapped batteries.

The domestic lead scrap industry has conformed to State and Federal environmental regulations for lead as well as to foreign regulations and agreements governing the sale and trade of lead products. Ambient air standards for lead in the United States were revised and made more stringent in 2008, as were lead emissions standards at battery recycling facilities in 2012. More stringent lead standards have led to the development of technological improvements that have reduced U.S. lead emissions, but made it more costly for smaller, less profitable secondary lead smelters to comply with these standards. Smelters that continue to operate will likely demonstrate better environmental performance, striving for improved facility efficiency.

The trade pattern of lead scrap has also been affected by domestic environmental regulation, by regional trade agreements such as NAFTA, by international agreements such as the Basel Convention on the Control of Transboundary Movements of Hazardous Wastes and Their Disposal, and by revisions made in 2011 to the OECD guidelines. Canada and Mexico are leading trading partners for U.S. lead scrap and battery scrap imports and exports. Some U.S. companies have shifted a portion of their North American operations to Mexico, where labor and processing costs are lower and environmental emissions standards are less stringent. As more lead-bearing battery materials are exported to and recovered in countries such as Mexico, greater pressure is placed both on the United States by environmental groups to adopt manifesting requirements similar to those required by other countries, and on countries receiving battery waste from the United States to adopt stringent environmental standards similar to those that came into effect in January 2014 in the United States. Adoption of comparable standards could reduce global lead emissions and strengthen the competitiveness of U.S. recycling facilities.

\section{References Cited}

Barlas, Steve, 2006, The E-scrap export enigma: Scrap Magazine, September/October 2006, Institute of Scrap Recycling Industries, Inc., accessed November 12, 2013, at http://www.isri.org/news-publications/scrap-magazine/ scrap-articles/the-e-scrap-export-enigma.

Battery Council International, 2009, National recycling rate study: Chicago, Ill., prepared by SmithBucklin Corporation, 11 p., accessed April 15, 2013, at http://www. batterywholesaleonline.com/wp-content/uploads/2010/10/ BCI_recycling_study.pdf.

Battery Council International, 2012, National recycling rate study: Chicago, Ill., prepared by SmithBucklin Corporation, 9 p., accessed April 15, 2013, at http://archive.batterycouncil.org/Portals/0/BCI\%20Recycling\%20Rate $\% 20$ Study\%202007\%20-\%202011\%20Final\%20Report.pdf.

Battery Council International, 2013, State Recycling Laws: Battery Council International Web page, accessed April 24, 2013, at http://batterycouncil.org/?page=State_Recycling_Laws.

Bradford, Mark, 2011, The United States, China, and the Basel Convention on the Transboundary Movements of Hazardous Wastes and Their Disposal: Fordham Environmental Law Review, v. 8, no. 2, p. 305-349, accessed September 13, 2013, at http://ir.lawnet.fordham. edu/cgi/viewcontent.cgi?article $=1445 \&$ context=elr.

Carlin, J.F., Jr., 2014, Antimony, in Metals and minerals: U.S. Geological Survey Minerals Yearbook 2012, v. I, p. 6.1-6.8, accessed October 7, 2014, at http://minerals.er.usgs.gov/ minerals/pubs/commodity/antimony/myb1-2012-antim.pdf.

Commission for Environmental Cooperation, 2012, Hazardous trade?-An examination of U.S.-generated spent lead-acid battery exports and secondary lead recycling in Mexico, the United States and Canada; final draft report: Secretariat of the Commission for Environmental Cooperation, November 30, 2012, 70 p., accessed April 8, 2013, at http://www.cec.org/Storage/ 142/16758_SLAB-publicdraft-30Nov_en.pdf.

Commission for Environmental Cooperation, 2013, Hazardous trade?-An examination of U.S.-generated spent leadacid battery exports and secondary lead recycling in Canada, Mexico, and the United States: Secretariat of the Commission for Environmental Cooperation, April 2013, 64 p., accessed March 28, 2014, at http://www3.cec.org/ islandora/en/item/11220-hazardous-trade-examination-usgenerated-spent-lead-acid-battery-exports-and-en.pdf. 
D’Ambrosio, Dan, 2013, Used electronics - Opportunity or toxic waste?: USA Today, September 26, 2013, accessed April 24, 2014, at http:/www.usatoday.com/story/money/ business/2013/09/26/e-waste-empire-middlebury-vermontdiscarded-electronics/2880359/.

The Doe Run Company, 2013, Herculaneum smelter update: The Doe Run Company, press release, November 7, 2013, accessed November 26, 2013, at http://www.doerun.com/ MediaCenter/NewsReleases/Article/Herculaneum-SmelterUpdate.aspx.

Edelstein, D.L., 2001, Copper, in Metals and minerals: U.S. Geological Survey Minerals Yearbook 1999, v. I, p. 22.1-22.29, accessed March 28, 2014, at http://minerals. er.usgs.gov/minerals/pubs/commodity/copper/240499.pdf.

Edelstein, D.L., 2013, Copper, in Metals and minerals: U.S. Geological Survey Minerals Yearbook 2011, v. I, p. 20.1-20.25, accessed March 28, 2014, at http://minerals. er.usgs.gov/minerals/pubs/commodity/copper/myb1-2011coppe.pdf.

Guberman, D.E., 2013a, Lead, in Metals and minerals: U.S. Geological Survey Minerals Yearbook 2011, v. I, p. 42.1-42.18, accessed May 15, 2013, at http://minerals. er.usgs.gov/minerals/pubs/commodity/lead/myb1-2011lead.pdf.

Guberman, D.E., 2013b, Lead, in U.S. Geological Survey, Mineral commodity summaries 2013: U.S. Geological Survey, p. 90-91. [Also available at http://minerals.usgs. gov/minerals/pubs/mcs/2013/mcs2013.pdf.]

Guberman, D.E., 2015, Lead, in Metals and minerals: U.S. Geological Survey Minerals Yearbook 2012, v. I, p. 42.1-42.16, accessed May 15, 2015, at http://minerals. er.usgs.gov/minerals/pubs/commodity/lead/myb1-2012lead.pdf.

IndexMundi.com, 2013, Lead monthly price-US dollars per metric ton: IndexMundi.com, accessed November 14, 2013, at http://indexmundi.com/commodities/?commodity=lead\& ampamp;months $=240$.

Johnson Controls, 2013, Leading the way in battery recycling, accessed May 8, 2013, at http://www.johnsoncontrols. com/content/dam/WWW/jci/ps/press_kit/22083_JCI_ FSRecycling_RL_1-2.pdf.

Johnson, Tim, 2013, As U.S. tightens rules on lead emissions, battery recycling has moved to Mexico: McClatchy Newspapers, Washington bureau, accessed April 24, 2013, at http:/www.mcclatchydc.com/2013/03/25/186693/as-ustightens-rules-on-lead-emissions.html.
Letsrecycle.com, 2013, Prices-Metals: Letsrecycle.com, accessed November 8, 2013, at http://www.letsrecycle.com/ prices/metals/.

Luther, Linda, 2010, Managing electronic waste-Issues with exporting E-waste: Congressional Research Service report R40850, October 7, 2009, 12 p., accessed September 9, 2014, at http://www.cnie.org/nle/crsreports/10Oct/R40850.pdf.

National Automobile Dealers Association, 2012, NADA Data 2012 - State-of-the-industry report: McLean, Va., National Automobile Dealers Association, 21 p.

Occupational Knowledge International, 2011, Exporting hazards - U.S. shipments of used lead batteries to Mexico take advantage of lax environmental and worker health regulations: Occupational Knowledge International and Fronteras Comunes, 24 p. and 7 appendixes, accessed May 15, 2013, at http://www.okinternational.org/docs/ Exporting\%20Hazards_Study_100611v5.pdf.

Papp, J.F., 2013, Recycling-Metals, in Metals and minerals: U.S. Geological Survey Minerals Yearbook 2011, v. I, p. 61.1-61.5, accessed June 15, 2013, at http://minerals. er.usgs.gov/minerals/pubs/commodity/recycle/myb1-2011recyc.pdf.

Recycling Today, 2013, Exide idles California lead smelter: Recycling Today, April 26, 2013, accessed May 15, 2013, at http://www.recyclingtoday.com/exide-vernon-lead-smeltercompliance.aspx.

Schmidt, C.W., 2010, Lead in air-Adjusting to a new standard: Environmental Health Perspectives, v. 118, no. 2, p. A76-A79, accessed April 25, 2013, at http://www.ncbi. nlm.nih.gov/pmc/articles/PMC2831943/.

Smith, G.R., 1996, Lead, in Metals and minerals: U.S. Geological Survey Minerals Yearbook 1995, v. I, 22 p., accessed March 28, 2014, at http://minerals.er.usgs.gov/ minerals/pubs/commodity/lead/380496.pdf.

Smith, G.R., 1997, Lead, in Metals and minerals: U.S. Geological Survey Minerals Yearbook 1996, v. I, 20 p., accessed March 28, 2014, at http://minerals.er.usgs.gov/ minerals/pubs/commodity/lead/380495.pdf.

Smith, G.R., 2001, Lead, in Metals and minerals: U.S. Geological Survey Minerals Yearbook 1999, v. I, p. 44.1-44.23, accessed March 28, 2014, at http://minerals. er.usgs.gov/minerals/pubs/commodity/lead/380499.pdf.

Smith, G.R., 2004, Lead recycling in the United States in 1998, chap. F of Sibley, S.F., ed., Flow studies for recycling metal commodities in the United States: U.S. Geological Survey Circular 1196-A-M, accessed April 24, 2013, at http://pubs.usgs.gov/circ/2004/1196am/c1196a-m_v2.pdf. 
U.S. Bureau of Labor Statistics, 2013, Consumer Price Index: U.S. Department of Labor, Bureau of Labor Statistics, accessed March 28, 2014, at http://www.bls.gov/cpi/.

U.S. Census Bureau, 2013, Statistical notices and corrections: U.S. Census Bureau, accessed April 26, 2013, at http://www.census.gov/foreign-trade/statistics/ corrections/index.html.

U.S. Department of Transportation, 2013, Table 1-15Annual U.S. motor vehicle production and factory (wholesale) sales (thousands of units): U.S. Department of Transportation, Bureau of Transportation Statistics, accessed October 6, 2014, at http://www.rita.dot.gov/bts/ sites/rita.dot.gov.bts/files/publications/national_transportation_statistics/html/table_01_15.html_mfd.

U.S. Environmental Protection Agency, 1997, 40 CFR Part 63-National emission standards for hazardous air pollutants from secondary lead smelting-Direct final rule-Amendments to rule: Federal Register, v. 62, no. 114, June 13, p. 32209-32223.

U.S. Environmental Protection Agency, 2010, Revisions to OECD imports and exports rule: U.S. Environmental Protection Agency Web page on wastes, accessed April 24, 2014, at http://www.epa.gov/solidwaste/hazard/ international/oecd-slab-rule.htm.

U.S. Environmental Protection Agency, Office of Resource Conservation and Recovery, 2011a, Electronics waste management in the United States through 2009: U.S. Environmental Protection Agency, Office of Resource Conservation and Recovery report EPA 530-R-11-002, May 2011, 49 p., accessed April 14, 2013, at http://www. epa.gov/osw/conserve/materials/ecycling/docs/fullbaselinereport2011.pdf.

U.S. Environmental Protection Agency, Office of Resource Conservation and Recovery, 2011b, Municipal solid waste generation, recycling, and disposal in the United StatesTables and figures for 2010: U.S. Environmental Protection Agency, Office of Resource Conservation and Recovery, December 2011, 29 tables, 26 figs., accessed April 14, 2013, at http://www.epa.gov/osw/nonhaz/municipal/pubs/2010 MSW_Tables_and_Figures_508.pdf.

U.S. Environmental Protection Agency, 2012a, 40 CFR Part 63-National emissions standards for hazardous air pollutants from secondary lead smelting; Final rules: Federal Register, v. 77, no. 3, January 5, 2012, p. 556-591, http:/www.gpo.gov/fdsys/pkg/FR-2012-01-05/pdf/201132933.pdf.
U.S. Environmental Protection Agency, 2012b, Statistics on the management of used and end-of-life electronics: U.S. Environmental Protection Agency Web page, accessed May 16, 2013, at http://www.epa.gov/osw/conserve/materials/ecycling/manage.htm.

U.S. Environmental Protection Agency, 2013, Batteries: U.S. Environmental Protection Agency Web page on wastes, accessed April 24, 2013, at http://www.epa.gov/ waste/conserve/materials/battery.htm.

U.S. Environmental Protection Agency, 2014, 40 CFR Part 273-Standards for universal waste management, in Electronic code of Federal regulations: U.S.

Government Publishing Office, accessed March 28, 2014, at http://www.ecfr.gov/cgi-bin/text-idx?c=ecfr\&tpl=/ ecfrbrowse/Title40/40cfr273_main_02.tpl.

U.S. Geological Survey, 1996-2013, Lead, in Metals and minerals: U.S. Geological Survey Minerals Yearbook, 1995-2011, v. 1 [variously paged], accessed November 12, 2014, at http://minerals.er.usgs.gov/ minerals/pubs/commodity/lead/.

U.S. Geological Survey, 2013, Metal prices in the United States through 2010: U.S. Geological Survey Scientific Investigations Report 2012-5188, 204 p., available only at http://pubs.usgs.gov/sir/2012/5188.

U.S. Geological Survey, 2014, Lead statistics, in Kelly, T.D., and Matos, G.R., comps., Historical statistics for mineral and material commodities in the United States (2013 version): U.S. Geological Survey Data Series 140, 4 p., accessed May 16, 2014, at http://minerals.usgs.gov/minerals/pubs/ historical-statistics/.

U.S. International Trade Commission, 2013, Interactive tariff and trade dataweb: U.S. International Trade Commission, accessed May 13, 2013, at http://dataweb.usitc.gov/.

Wilburn, D.R., 2014, Comparison of the U.S. lead recycling industry in 1998 and 2011: U.S. Geological Survey Scientific Investigations Report 2014-5086, 20 p., http://dx.doi.org/10.3133/sir20145086.

Wilburn, D.R., and Buckingham, D.A., 2006, Apparent consumption vs. total consumption-A lead-acid battery case study: U.S. Geological Survey Scientific Investigations Report 2006-5155, 9 p., accessed June 13, 2013, at http://pubs.usgs.gov/sir/2006/5155/. 
Manuscript approved August 8, 2015

Prepared by the USGS Science Publishing Network Edited by James R. Estabrook, Reston PSC Illustrations and layout by Caryl J. Wipperfurth, Raleigh PSC

For additional information, please contact: Director, National Minerals Information Center U.S. Geological Survey 12201 Sunrise Valley Drive 988 National Center

Reston, VA 20192

Email: nmicrecordsmgt@usgs.gov

Or visit the USGS Minerals Information Web site at http://minerals.usgs.gov/minerals/ 
